\title{
The Lawsonian Stage - the Eoconodontus notchpeakensis (Miller, 1969) FAD and HERB carbon isotope excursion define a globally correlatable terminal Cambrian stage
}

\author{
ED LANDING, STEPHEN R. WESTROP \& JONATHAN M. AdRAIN
}

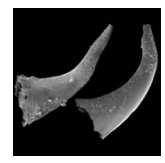

\begin{abstract}
The best definition for the base of the terminal Cambrian (Stage 10) is the conodont Eoconodontus notchpeakensis FAD \pm onset of the HERB carbon isotope excursion. These horizons allow precise intercontinental correlations in deep marine to peritidal facies. The agnostoid Lotagnostus americanus (Billings, 1860) FAD has been suggested as a Stage 10 base, but restudy of types and typotypes shows that the species occurs only in Late Cambrian (Sunwaptan) debris flow boulders in Quebec (Westrop et al., this volume). Non-Quebec reports of "L. americanus" are an amalgum of small samples of often poorly documented specimens with effaced-highly furrowed cephala and pygidia and with or without a highly trisected pygidial posteroaxis. Many of these occurrences have local species names, but no evidence suggests that they record intraspecific variation of a globally distributed taxon. They are not synonyms of L. americanus. Lotagnostus, largely a dysoxic form, does not allow precise correlation into oxygenated platform facies. Another proposal used the conodont Cordylodus andresi FAD as a Stage 10 base, but other work shows this FAD is diachronous. An unrealistic approach to L. americanus' systematics and the correlation uncertainty of $C$. andresi are overcome by defining a Stage 10 base at the globally recognizable E. notchpeakensis FAD, with the $C$. andresi FAD a useful proxy on cool-water continents. The "Lawsonian Stage", named for Lawson Cove in western Utah, has a basal GSSP at the E. notchpeakensis FAD and replaces informal Stage 10. The Lawsonian, $150 \mathrm{~m}$-thick in western Utah, underlies the basal Ordovician Iapetognathus Zone. $\bullet$ Key words: Cambrian, Lawsonian Stage, Utah, United States, conodonts, agnostoids, HERB excursion.
\end{abstract}

LANDING, E., WeSTROP, S.R. \& ADRAIN, J.M. 2011. The Lawsonian Stage - the Eoconodontus notchpeakensis FAD and HERB carbon isotope excursion define a globally correlatable terminal Cambrian stage. Bulletin of Geosciences 86(3), 621-640 (7 figures, appendix). Czech Geological Survey, Prague. ISSN 1214-1119. Manuscript received December 30, 2010; accepted in revised form August 8, 2011; published online September 19, 2011; issued September 30, 2011.

Ed Landing, New York State Museum, 222 Madison Avenue, Albany, NY, 12230, USA; elanding @ mail.nysed.gov - Stephen R. Westrop, Oklahoma Museum of Natural History and School of Geology and Geophysics, 2401 Chautauqua Avenue, University of Oklahoma, Norman, Oklahoma 73072, USA; swestrop@ou.edu・Jonathan M. Adrain, Department of Geoscience, University of Iowa, 121 Trowbridge Hall, Iowa City, Iowa 73072, USA

The high provinciality of Cambrian biotas has made intercontinental and interfacies correlations difficult and has led to localized schemes of series and stages that subdivide the Cambrian (e.g., Geyer \& Shergold 2000, Shergold \& Geyer 2003). Thus, the International Subcommission on Cambrian Stratigraphy (ISCS) has worked to devise a globally applicable nomenclature for division of the Cambrian. In the last decade, agreement was reached to divide the Cambrian into four series (proposed by Landing 1998a, b), each of which had two or three stages for a total of ten stages (e.g., Babcock et al. 2005). To develop a standardized Cambrian nomenclature of global series and stages, the ISCS has evaluated use of the first appearance datum (FAD) of geographically widespread taxa, often combined with such non-conventional correlation techniques as carbon isotope excursions. These procedures have established a global stratotype section and point (GSSP) for a number of Cambrian stages and series, as well as the base and top of the system (Fig. 1).

Of the presently unnamed and formally undefined global Cambrian divisions, the terminal Cambrian (Stage 10) is a very significant unit. Stage 10 is part of a Middle Cambrian-Early Ordovician time when lower-level (familyand genus-level) diversity fell in the marine realm (Sepkoski 1981, 1997). However, several higher level taxa, as euconodonts, cephalopods, polyplacophorans, and bryozoans that appear in the upper Jiangshanian (Stage 9)-Stage 10 interval went on to diversify later in the Ordovician 


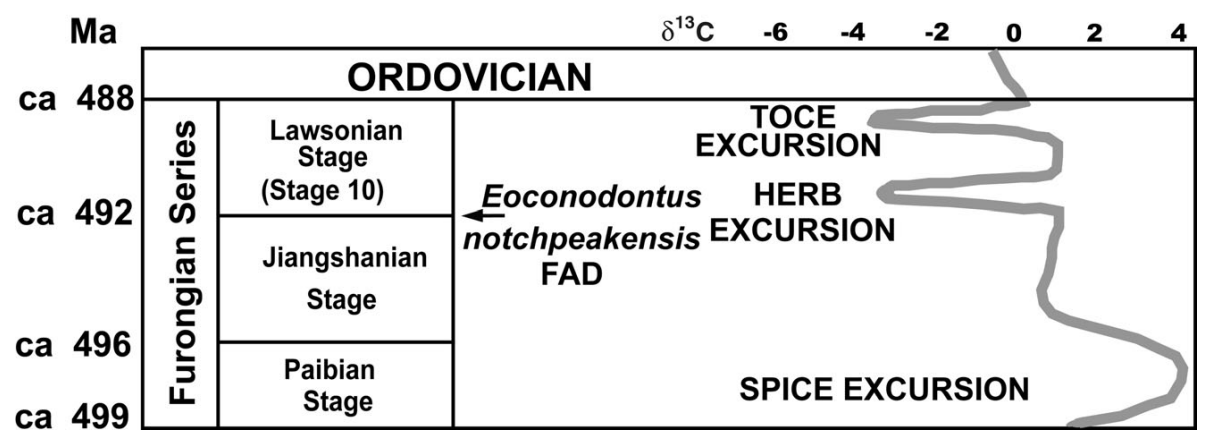

Figure 1. Stage-level subdivision of the terminal Cambrian. Modified from Zhu et al. (2007, fig. 1) with addition of HERB carbon isotope excursion. radiation (Sepkoski 1995, Landing et al. 2010). [The term "Jiangshanian Stage" (Fig. 1) reflects the ISCS' vote in September 2010 to replace informal Stage 9 by the Jiangshanian Stage with a GSSP at Dubian village, Zhejiang, China (e.g., Peng et al. 2005)].

The top of Stage 10 is the basal Ordovician Iapetognathus fluctivagus Zone (Cooper et al. 2001). However, formal agreement does not exist on the criteria for defining the base, proposing a GSSP, or naming this important, terminal Cambrian stage. In 2004, the ISCS voted to adopt the proposal "Should a stage-level GSSP be established at the level of Lotagnostus trisectus or another fossil in a comparable stratigraphic position?"

Cambrian trilobite and agnostoid workers have shown particular enthusiasm for the first part of this proposal. Agnostoids have been used to define the GSSPs of a number of Middle and Upper Cambrian series and stages (e.g., Fig. 1, Paibian and Jiangshanian stages), even though these taxa characterize dysoxic facies and often do not allow precise correlations onto coeval shallow-water, oxygenated platforms. [The designations "Lower," "Middle," and "Upper" Cambrian are informal subsystem-level divisions that correspond, respectively, to the Terreneuvian + Series 2, Series 3, and Furongian Series (Fig. 1) (see Landing 2007). In accordance with stratigraphic convention, the two or three major divisions of a system or period must be capitalized (North American Commission on Stratigraphic Nomenclature 1983).]

Obviously, the FADs of agnostoids cannot be used to subdivide the entire Cambrian. Non-trilobite/non-agnostoid taxa define, or will likely define, the GSSP of the Terreneuvian and Fortunian Stage (trace fossils), Stage 2 (probably small shelly fossils), Stage 3 (possibly small shelly fossils), and base of the Ordovician (conodonts). Thus, there is no reason that the Stage 10 base should be defined by the FAD of a trilobite or agnostoid.

The 2004 vote was followed by three proposals to define the Stage 10 base. The first was Peng \& Babcock's (2005), which focused on the Lotagnostus trisectus provision of the 2004 vote. They synononymized L. trisectus (Salter, 1864) and nine other named species earlier referred to Agnostus Brongniart, 1822; Goniagnostus Howell, 1935; and Lotagnostus Whitehouse, 1936, with Lotagnostus americanus (Billings, 1860). Peng \& Babcock (2005) allowed greater morphologic variability (from relatively effaced to strongly furrowed cranidia and pygidia) in L. americanus than that allowed by Ludvigsen et al. (1989, p. 12) or Rushton (2009) (summarized below and discussed in detail in Westrop et al., this volume). This synonymy suggested a global distribution of $L$. americanus (Fig. 2) in the more offshore, dysoxic Hedenaspis biofacies of the middle Upper Cambrian (e.g., Taylor \& Cook 1976), and led Peng \& Babcock (2005) to propose an L. americanus' FAD as the Stage 10 base.

A second proposal that followed the "or another fossil" option of the 2004 vote to define the Stage 10 base was Miller et al.'s (2006). They used the FAD of the conodont Cordylodus andresi Viira \& Sergeeva (in Kaljo et al., 1986) in the middle Lawson Cove section in the Wah Wah Mountains, western Utah, as a GSSP for a Stage 10 base. This proposal derived from Ross et al.'s (1997) definition of the base of the Cordylodus proavus Zone at the C. andresi FAD at the nearby Lava Dam 5 section. Miller et al.'s proposal dealt with a carbonate platform succession, not the more distal facies characteristic of "Lotagnostus americanus", and equated the Stage 10 base with the turnover of conodonts and trilobites at the base of the Laurentian Eurekia apopsis Zone. Although never voted on, the Miller et al. (2006) proposal was regarded by individuals in the ISCS as featuring a horizon that is too high in the Cambrian to serve as a Stage 10 base.

With the passage of time and accumulation of improved data, the limitations and unexpected implications of the FADs of Lotagnostus americanus and Cordylodus andresi have become evident to us. We evaluate herein the relative utility of these earlier proposed biostratigraphic standards for the base of Stage 10, and summarize a third Stage 10 proposal (Landing et al. 2010b). This proposal defines the base of Stage 10 under the option of "another fossil" and uses the FAD of a conodont species that occurs at the onset of a major carbon isotope excursion.

Available information allows definition of a GSSP for Stage 10 which relies only in part on the FAD of a fossil. Our proposal uses the FAD of a particularly widespread, apparently eurytopic species, the conodont Eoconodontus notchpeakensis (Miller, 1969). This euconodont is a well 


\section{Lotagnostus americanus and related species (arrows)}

\section{Eoconodontus notchpeakensis FAD} base defined $=* \quad \mathbf{p}=$ platform, $\mathbf{d}=$ dysoxic, ? = may be at zone's base

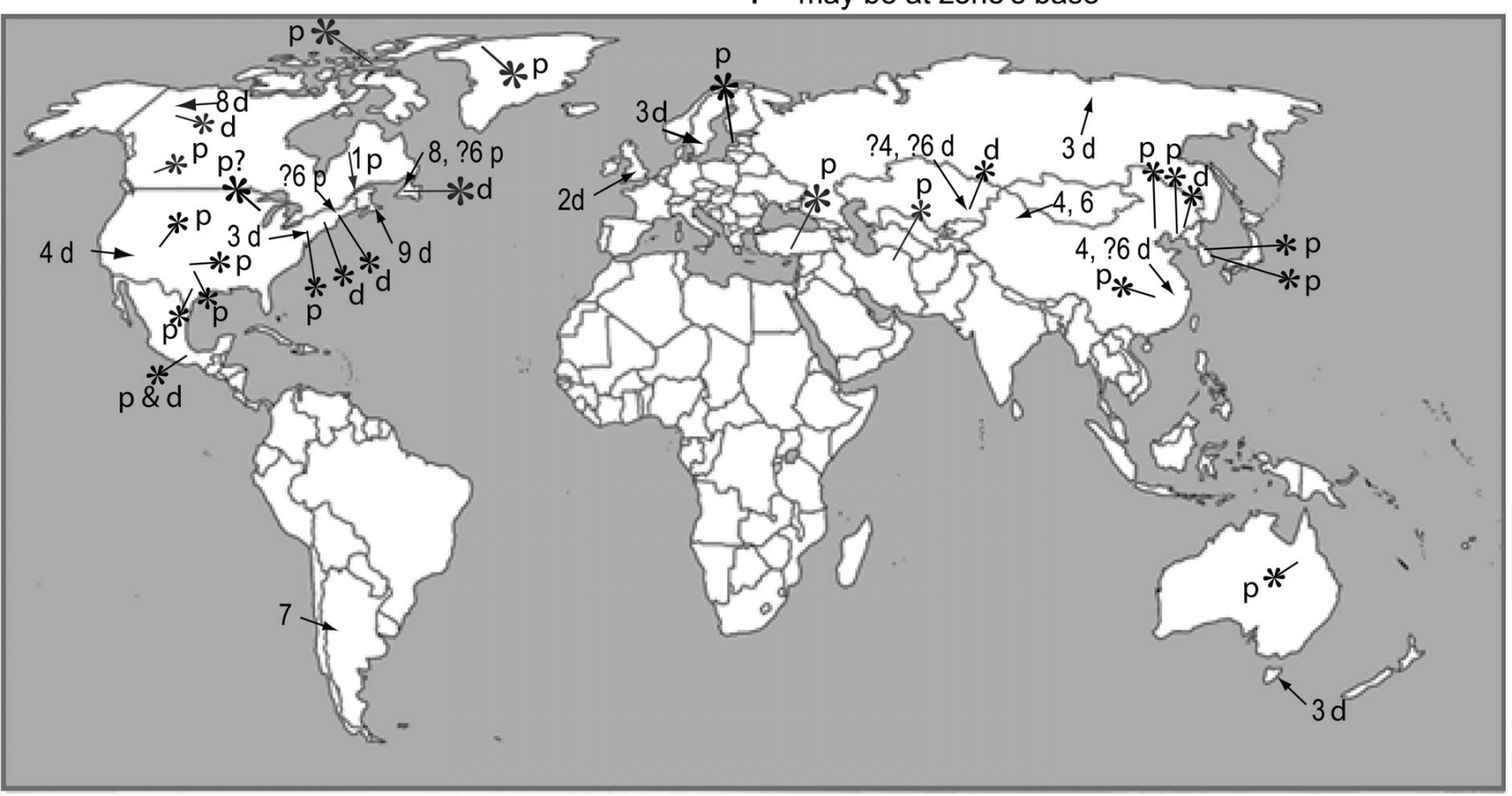

1, L. americanus; 2, L. trisectus; 3, L. "trisectus" ; 4, L. obscurus; 5 L. asiaticus, L. punctatus; 6, L. hedini;

7, L. verrucosus; 8, L. sp. indet (multiple species); 9, L. germanus, L. cf. L. trisectus; $?=$ questionable identification

Figure 2. Lotagnostus spp. occurrences (arrows) in marginal/dysoxic settings and Eoconodontus notchpeakensis FAD base (lines with asterisks). For sources of localities, see Appendix.

established and well illustrated species known from a bielemental apparatus that includes bilaterally symmetrical and asymmetrical laterally, basally deflected conoidal elements. Both of these elements are laterally compresssed, have anterior and posterior keels, lack longitudinal microstriae, and have a basal cavity that does not reach the tip of the element (see, for example, scanning microscopy figures and line drawings in Miller 1980 and Landing et al. 2007; Nicoll 1991, p. 530, claimed a "septimembrate apparatus" in the species but never illustrated it). Eoconodontus notchpeakensis is known from continental rise to peritidal facies on all Cambrian continents (Fig. 2, Appendix) and can be used to define the Stage 10 base (Landing et al. 2010b). We also incorporate an important "non-conventional" correlation tool - a major, globally recognized carbon isotope excursion, the HERB event in the lower part of the E. notchpeakensis range (Ripperdan 2002) - whose utility in defining the base of Stage 10 has not been recognized previously (Fig. 1). Finally, well documented sections of the western Great Basin allow designation of a reference section for the GSSP of Stage 10 at the well known Steamboat Pass section in the House Range as the global stratotype of the "Lawsonian Stage" (newly documented proposal) for the terminal Cambrian (see also Miller et al., this volume, for further documentation).

\section{The "Lotagnostus americanus problem"}

\section{Taxonomy}

Obviously, any species that is used for global correlation of stage and series boundaries must be demonstrably the same species in all regions from which it is reported. The case for a single, globally identifiable species of Lotagnostus in upper Sunwaptan and correlative strata was made by Peng \& Babcock (2005), who united a variety of nominal species from different Cambrian paleocontinents under the name, L. americanus (Billings, 1860). Unfortunately, this work did not benefit from extensive restudy of relevant types, and most of the images published by Peng and Babcock (2005, fig. 2) were apparently reproduced from earlier works. In a companion paper (Westrop et al., this volume), we evaluate the record of $L$. americanus and other species in North America by the use of type and new material from Laurentia and Avalonia. Together with a recent paper on 


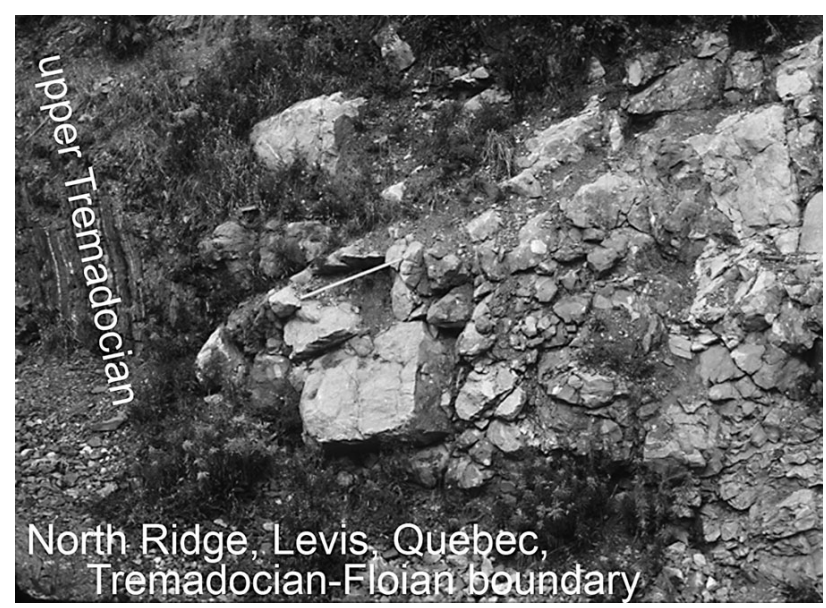

Figure 3. Shelf margin-derived boulders of the Lower Ordovician (Tremadocian-Floian boundary) North Ridge debris flow, Levis, Quebec (e.g., Landing et al. 1992) yielded topotype Lotagnostus americanus (Billings, 1860) and Rasetti's (1944) specimen. $1.0 \mathrm{~m}$ scale at center-left. Figure shows lower half of debris flow.

L. trisectus (Salter, 1864) by Rushton (2009), our work questions the extremely broad concept of $L$. americanus adopted by Peng \& Babcock (2005) and thus has profound implications for the recognition and correlation of the base of Stage 10. Our conclusions are summarized briefly below.

In his original description of fossils from Lévis, Quebec, Billings (1860, p. 301; misprinted in article as 201) noted the presence of "several groups of species, each occurring in a rock somewhat different in appearance from that which contains the others". Wisely, he kept these lithologically distinct grouping separate from each other, and referred to them as "limestones Nos 1, 2, 3 and 4". Sclerites of L. americanus were recovered from Limestone No. 1, which presumably represents an Upper Cambrian boulder in the middle Lower Ordovician, North Ridge debris flow; the associated trilobite assemblage is correlative with the Sunwaptan Keithia subclavata Fauna (Ludvigsen et al. 1989). This debris flow is in the frontal thrust of the Taconic allochthon at Lévis (Fig. 3; see Landing et al. 1992). Lotagnotus americanus was based on three sclerites, the holotype pygidium and two cephala that, because they were assigned questionably by Billings, are topotypes, rather than paratypes (Rushton 2009). Rasetti (1944, p. 233, table 1) identified material from coeval (i.e., Keithia subclavata Fauna; Ludvigsen et al. 1989, p. 10) boulders 15 and 37 from the North Ridge debris flow as L. americanus, and Ludvigsen \& Westrop (in Ludvigsen et al. 1989) expanded the species to include L. obscurus Palmer, 1955. Following restudy of the types, we now recognize the latter as a distinct species (Westrop et al., this volume).

Restudy of specimens from the Billings and Rasetti collections, including some that were previously unfigured (Westrop et al., this volume, figs 5D-G, 6A-D), allows us to conclude that the material of Lotagnostus americanus from the North Ridge debris flow (including sclerites illustrated by Rushton 2009, fig. 1J-O) may be interpreted as a single species. Following Rushton (2009, p. 278), we exclude a younger cephalon from the Shallow Bay Formation, western Newfoundland (Ludvigsen et al. 1989, pl. 1, fig. 17), but stop short of transferring it to L. trisectus (Salter, 1864). As revised by Westrop et al. (this volume), L. americanus is now an exclusively Laurentian species that occurs with certainty only at the type locality in Quebec. Its diagnostic character states include a weakly convex glabella that is outlined completely on the weakly scrobiculate external surface of the cephalon, with segmentation clearly identifiable only posteriorly near the basal lobes, which are relatively short. F2, the transglabellar F3, and M2 lobes are all clearly expressed on internal molds. The posteroaxis of the pygidium shows faint trisection in larger specimens, but this may not be developed in smaller individuals. F2 is not connected across the axis, and the acrolobes are unconstricted. This combination of characters differentiates L. americanus from all of the nominal species illustrated by Peng \& Babcock (2005, fig. 2.5-2.27) and included under their concept of L. americanus.

Lotagnostus obscurus Palmer, 1955 (Westrop et al., this volume, fig. 7), is, among its other features, more effaced than L. americanus and is more convex, particularly its pygidium. These two species do share relatively short basal glabellar lobes. As recognized by Ludvigsen \& Westrop (in Ludvigsen et al. 1989, p. 12) and Rushton (2009, p. 278), these glabellar lobes differentiate them from both L. asiaticus Treodsson, 1937, and L. punctatus Lu (in Wang, 1964), which are characterized by long basal lobes. Peng \& Babcock (2005, p. 112) misinterpreted Ludvigsen and Westrop's discussion to say that the latter authors proposed the synonymy of L. americanus, L. asiaticus, and L. punctatus. However, the fact that Ludvigsen \& Westrop (in Ludvigsen et al. 1989, p. 12) did not include the latter two species in the synonymy list of L. americanus clearly underscores the fact that they considered all three to be distinct species.

New material and archival specimens from the Avalon Terrane in Nova Scotia (Westrop et al., this volume) complicate the interpretation of L. trisectus from Avalonian Britain. Rushton (2009, fig. 1A-I, P) revised L. trisectus, designated a neotype, and illustrated several additional topotypes from the White-leaved Oak Shale at Malvern, England. Unfortunately, compaction has distorted all of the specimens available from the type area. Similarly, other exoskeltons and isolated sclerites from North Wales (Rushton 2009, fig. 2A-D, G, K, L) have suffered even more from tectonic and taphonomic effects. Consequently, details of the morphology, particularly of the glabella, cannot be interpreted easily. As far as can be determined, 
uncompacted pygidia from the Chesley Drive Group (Westrop et al., this volume, fig. 2) along MacNeil Brook, Nova Scotia (Hutchinson 1952), are quite similar to the topotypes of L. trisectus. Associated cephala preserved in full relief have faint F2 furrows and M3 lobes that are barely expressed, which separate them from three dimensionally preserved cephala from Sweden, Argentina, and Siberia that have been assigned to L. trisectus (e.g., Westergård 1922, Shergold et al. 1995, Pegel 2000). These cephala from outside Avalon have glabellae with deeply incised F2, well defined M3, and basal lobes that are notched into the posteroglabella behind M2. Thus, undistorted, "L. trisectus-like" species differ in the expression of the glabellar lobes and furrows, and we cannot be sure as to which of these alternate morphologic conditions occurs in flattened L. trisectus from the type area. As a result, the name $L$. trisectus cannot be applied with any confidence beyond England and Wales, and this has obvious consequences for a global correlation based on Lotagnostus.

\section{Stratigraphic and paleogeographic distribution of Lotagnostus}

Our revision (Westrop et al., this volume) of Lotagnostus indicates that there are four species on the Laurentia paleocontinent. These include L. americanus, L. obscurus, L. "hedini", and L. cf. L. trisectus sensu Rasetti, 1959. In addition, there are likely two more Lotagnostus species in the Nova Scotia, Canada, part of the western Avalon paleocontinent. The latter species include L. germanus (Matthew, 1903) and L. cf. L. trisectus. If the cephala and pygidia of L. cf. L. trisectus from Nova Scotia turn out to record the uncompacted morphology of the type species from Avalonian Britain, then L. "trisectus" from Sweden and Siberia record, at a minimum, an additional species (Westrop et al., this volume).

The various Chinese terranes have yielded at least three additional, strongly furrowed species: Lotagnostus hedini (Treodsson, 1937), L. asiaticus Troedsson, 1937, and L. punctatus Lu (in Wang, 1964). Yet more species may be represented by L. "trisectus" in such areas as Argentina (Shergold et al. 1995) and Tasmania (Bao \& Jago 2000), with effaced species from Queensland described under the name Distagnostus Shergold, 1972. Thus, a GSSP based on a single species of Lotagnostus is untenable as a number of Lotagnostus species occur in separate regions of the Cambrian world. However, the question remains, could an FAD based on a set of non-effaced Lotagnostus species offer an alternative means to define the base of Stage 10? That is, are the FADs of such species as L. americanus, L. trisectus, L. "trisectus" sensu Westergård, L. asiaticus, and L. punctatus sufficiently close in age to cobble together a GSSP?
In Quebec, topotype Lotagnostus americanus is associated with a trilobite fauna that places it in the Kiethia schucherti Fauna of Ludvigsen et al. (1989), which correlates with the Prosaukia pyrene Subzone of Texas (Longacre, 1970) and the upper Illaenurus Zone of Alberta (Westrop, 1986). It is therefore significantly older than the FAD of Eoconodontus notchpeakensis. Lotagnostus cf. L. trisectus of Rasetti (1959) is older still as it is part of an assemblage that is likely equivalent to the Onchonotus richardsoni Fauna in the Cow Head Group of Newfoundland (Ludvigsen et al. 1989, p. 9) and the lower Illaenurus Zone of Alberta (see Westrop et al., this volume, for stratigraphic ranges in Laurentia).

In western Laurentia, the types of Lotagnostus obscurus Palmer, 1955, from the Eureka District of Nevada are poorly constrained biostratigraphically, although a paratype cephalon (USNM 123557a) is associated with an undescribed species of Bienvillia Clark, 1924, which suggests that it is no older than the Onchonotus richardsoni Fauna (e.g., see Ludvigsen et al. 1989, p. 15). About $115 \mathrm{~km}$ to the northeast at Barton Canyon in the Cherry Creek Range of Nevada (Adrain \& Westrop 2004), L. cf. L. obscurus Palmer (Westrop et al., this volume) occurs with a trilobite assemblage that includes Hungaia Walcott, 1914, and Naustia Ludvigsen, 1982. This horizon is $133.1 \mathrm{~m}$ below a trilobite fauna described by Adrain \& Westrop (2004) that correlates into the upper Illaenurus Zone and the Prosaukia pyrene Subzone. It therefore likely represents the oldest occurrence of Lotagnostus in Laurentia, and probably correlates into the lower Illaenurus Zone or possibly older strata. Lotagnostus sp. indet from the Mackenzie Mountains of northern Canada (= L. "americanus" of Westrop 1995; see Westrop et al., this volume) is roughly the same age as $L$. cf. L. obscurus.

Correlation of these Laurentian occurrences of Lotagnostus with successions on other Cambrian paleocontinents is not easy, but the FAD of Eocondontus notchpeakensis (see below) provides a constraint. In Baltica, this horizon is likely in the Peltura scarabaeoides Zone, but could be as old as the Peltura minor Zone. As discussed below, this conclusion is based on purported elements of Proconodontus muelleri Miller, 1969, that were illustrated by Müller \& Hinz (1991, fig. 22B, C). These elements differ from those of $P$. muelleri sensu strictu in that their basal cavities do not extend to the tip of the element they are consequently comparable to E. notchpeakensis elements. However, the precise provenance and repository numbers of these specimens are not recorded by Müller \& Hinz (1991), and it cannot be determined if they are from the middle or upper Peltura Zones.

Lotagnostus "trisectus" in Sweden appears in the Ctenopyge spectablis Subzone of the P. minor Zone and ranges through the $C$. linnarsoni Subzone of the Peltura scarabaeoides Zone (Ahlberg 2003, fig. 2); the lower part 
of this interval was subsequently recast as the " $L$. americanus Zone" by Terfelt et al. (2008) and Terfelt \& Ahlberg (2010). As noted by Ahlberg (2003), agnostoids show low diversity and are not abundant in the Swedish Furongian. The lowest occurrence of "L. americanus" specimens lies at a relatively abrupt change in polymeroid faunas, with five olenid species disappearing and eight species having their lowest occurrence (e.g., Terfelt et al. 2011, fig. 1). This faunal discontinuity has three possible explanations: 1) It is an artifact of collecting or preservation. 2) It reflects a possible change to a more dysoxic environment accompanied by the appearance of very spinose Ctenopyge species, smooth pelturines, and Lotagnostus followed by a later Furongian habitat change and the simultaneous disappearance of these olenids and Lotagnostus. Finally, 3) a cryptic unconformity may cut out part of the faunal record. Any of these possibilities would mean that the FAD of their "L. americanus" may not accurately record an origination. An interpretation that Terfelt \& Ahlberg's (2010) "L. americanus" has a diachronous FAD is suggested by Pseudagnostus rugosus Ergaliev, 1980, which is stated to occur in the lower-middle part of their "L. americanus" Zone in Baltica, Kazakhstan, and South China. Although Terfelt \& Ahlberg (2010) stated that this helped demonstrate the biostratigraphic significance of "L. americanus", they could not explain a report of $P$. rugosus in older strata of the Eolotagnostus decorus Zone (i.e., upper Jiangshanian Stage) in South China. This uncertainty may reflect an anomalously low range of $P$. rugosus or the possibility of the higher range of a Lotagnostus FAD in Asian successions.

Terfelt et al.'s (2008) proposal was made seemingly in anticipation that an "L. americanus" FAD would eventually define a Stage 10 base. More importantly, the lowest occurrence of L. "trisectus", as we interpret it, in Baltica is near or somewhat below the FAD of E. notchpeakensis, although is likely well above the oldest record of Lotagnostus in Laurentia (Westrop et al., this volume).

In Avalonian Britain, the entry of Lotagnostus trisectus is in the Peltura minor Zone in England or even the underlying upper Protopeltura praecursor Zone in North Wales (Davidek et al. 1998, Rushton 2009). In addition to showing possible diachroneity even within a small area of British Avalon, the British occurrences are thus somewhat lower than in Sweden. In contrast, the FAD of Lotagnostus in the well-collected successions of Avalonian eastern Canada is significantly higher, and not lower than the Peltura scarabaeoides Zone in southern New Brunswick (Matthew 1894); Cape Breton Island, Nova Scotia (Matthew 1903, Hutchinson 1952); and eastern Newfoundland (Hutchinson 1962, p. 35). These lowest occurrences of Lotagnostus are likely at or above the FAD of E. notchpeakensis and clearly younger than the lowest occurrences of Lotagnostus in Laurentia.
In northwest Hunan, China, Lotagnostus punctatus is an eponymous species of the L. punctatus-Hedinaspis regalis Zone, and occurs at the base of this zone (Peng 1992, fig. 3). The correlation into Laurentia is not well constrained, but the occurrence of the stratigraphically long-ranging genus Hedinaspis Treodsson in western Nevada (Taylor 1976) likely places the base of the zone at a relatively low level in the Sunwaptan Stage. Here, Hedinaspis regalis appears above the local range of the Steptoean Stage species Irvingella angustilibata Kobayasi and below the entry of such taxa as Naustia tyboensis (Taylor, 1976) that might indicate a correlation with the upper Sunwaptan.

Peng (1991) also correlated the base of the Lotagnostus punctatus-Hedinaspis regalis Zone into the PtychaspisTsinania Zone of North China, which corresponds to the Asioptychaspis Zone of Korea (Sohn \& Choi 2007). Correlation at the family level is admittedly fraught with difficulty. However, the occurrence of Ptychaspis, a close relative of Asioptychaspis, in the lower Sunwaptan Ellipsocephaloides Zone of Alberta is consistent with the suggestion that the base of the L. punctatus-H. regalis Zone falls below the upper Sunwaptan. This would make the FAD of L. punctatus significantly older than all of the other species discussed above.

We conclude that an alternative approach to a GSSP based on a FAD of selected Lotagnostus species fails because of diachroneity of first occurrences of the genus between continents.

\section{Paleoenvironmental distribution of Lotagnostus}

In Quebec and Newfoundland, Lotagnostus occurs in shallow-water, carbonate platform margin-derived, debris flow blocks (e.g., Ludvigsen et al. 1989). By comparison, the genus comes from dysoxic, mudstone-dominated, middle Upper Cambrian shelf facies in North American and British Avalon and Baltica (e.g., Landing 1996, Schovsbo 2001, Terfelt \& Ahlberg 2010). Other occurrences of "L. americanus" sensu Peng \& Babcock (2005) are from habitats that have been interpreted as or (in the earlier literature) show lithologic features consistent with the lowoxygen habitats of outer shelf/ramp or slope facies. As shown in Fig. 2 (see references in the Appendix), these include Laurentian localities in Nevada and possibly the melange blocks of Laurentian north Argentina; the KhosNelege River region, northeast Siberian Platform (Pegel 2001); the Maly and Bolishoi Karatau, Kazakhstan; and a number of areas in east Gondwana across China from Tien Shan to Anhui (see Peng \& Babcock 2005 and Appendix) and apparently from deep-water sequences in Tasmania and New Zealand. 
In addition to the systematic and biostratigraphic uncertainties noted above, the habitat association of most specimens further adds to the "Lotagnostus americanus problem". With exception of the east Laurentian specimens from debris flow blocks, trilobite associations that include Lotagnostus characteristically include forms that inhabited dysoxic/marginal facies, and this precludes highly resolved correlations onto the extensive carbonate platforms of the Late Cambrian.

\section{Reevaluating the Cordylodus andresi FAD}

Miller et al. (2006) proposed the FAD of the conodont Cordylodus andresi as the basis for a GSSP for the base of Stage 10, and described a GSSP in the middle Lawson Cove section, Wah Wah Mountains, western Utah. This proposal put the GSSP at the base of the Laurentian Eurekia apopsis Zone (trilobites) and Cordylodus proavus Zone (conodonts), and at a "biomere" horizon marked by abrupt faunal turnover in trilobites and conodonts (Fig. 4).

Cordylodus andresi has an abrupt lowest occurrence at the base of the $C$. proavus Zone at localities on the western and easter Laurentian platform (Miller et al. 2006, Landing et al. 2010, E. Landing, unpub. data in Westrop et al. 1981). However, available evidence indicates that the FAD of $C$. andresi is very diachronous globally. Szaniawski \& Bengtson (1998) and Landing et al. (2007) showed that C. andresi appears well below the level of $C$. proavus and somewhat below the FAD of Eoconodontus notchpeakensis in the cool water successions of Baltica (Sweden) and West Gondwanan Mexico (Oaxaca State). Although Miller \& Repetski (2009) dismiss these reports as a result of erosion and stratigraphic mixing, the simple facts are that $C$. andresi occurs with sub-C. proavus Zone conodonts (e.g., Proconodontus muelleri Miller, 1969, and P. serratus Miller, 1969) in studies on two cool-water paleocontinents. Indeed, in both the Swedish and Mexican successions, a "conventional" Great Basin-like succession of conodont species (e.g., Miller 1980) is present from the Proconodontus muelleri Zone through C. proavus Zone, and no evidence for re-working or the mixing of taxa characteristic of any conodont biostratigraphic zone or subzone is present. "Occam's razor" leads to the simplest conclusion that $C$. andresi has an early appearance in cool-water successions.

In addition, studies of slope successions maginal to carbonate platforms in Kazakhstan and western Newfoundland show $C$. andresi (reported as its junior synonym C. primitivus Bagnoli et al., 1987) appearing above the range of $E$. notchpeakensis and below that of $C$. proavus (Barnes 1988, Dubinina 2000). Landing (in Landing et al. 2007b, p. 51) re-interpreted purported "too old" specimens of C. proavus (i.e., Taylor et al. 1991) from continental slope deposits of northwest Vermont as C. andresi Viira \& Sergeeva (in Kaljo et al. 1986) - a species that was not described when Landing's (1983) study of the Highgate gorge succession appeared - a study in which $C$. andresi was reported as $C$. proavus. Finally, new data indicate a second occurrence of $C$. andresi with a Hungaia magnifica fauna from slope deposits in northwestern Vermont (E. Landing, unpublished data, 2010). As discussed below, although diachroneity does not allow a $C$. andresi FAD to serve as a global correlation horizon, the species has a key role in the proposal of a Stage 10 lower boundary.

\section{A new approach to Stage 10}

\section{Conodonts and the Jiangshanian-Stage 10 interval}

"Advanced" conodont animals, or euconodonts, have phosphatic conodont elements that grew by holoperipheral accretion - the addition of growth laminae to the element exterior while they were surrounded by soft tissue (e.g., Bengtson 1976). Euconodonts, key biostratigraphic aids for much of the Paleozoic and Triassic, first appear in the uppermost Jiangshanian, with the successive appearance of several species of the simple-cone genus Proconodontus Miller, 1969 (Fig. 4). Thus, P. tenuiserratus Miller, 1980, followed by $P$. muelleri Miller, 1969, appears with Jiangshanian trilobites of the upper Eolotagnostus decorus Zone in South China (Dong et al. 2004) and upper Kaolishania pustulosa Zone of North China (An 1982, Wang 1985; also Peng et al. 2009).

Late Cambrian euconodont assemblages are remarkably useful biostratigraphically - they are widespread, both geographically and in terms of habitats; many taxa show limited provincialism; and assemblages are largely composed of taxa that pose few problems in identification. The Jiangshanian conodont succession in North and South China can be easily compared to the lower part of Miller's (1969, 1978, 1980) Late Cambrian conodont succession which was developed primarily in the western and south-central United States.

The succession of conodont zones and subzones recognized by Miller (Fig. 4) has been used, with local modifications, by workers on different Cambrian paleocontinents, from shallow- to deep-water successions across Laurentia, Baltica, East and West Gondwana, Kazakhstan, and the Siberian and South China Platforms (Fig. 4). The relative uniformity of terminal Cambrian conodont zones means that a potential Stage 10 GSSP would not be based solely on the biostratigraphically isolated FAD of a rare organism, as Stage 10 agnostoids are in Baltica. Rather, a conodont-based Stage 10 base would be based on the FAD of a conodont that lies within a globally replicatable succession 
of older to younger conodont zones, each characterized by a number of conodont genera and species. Briefly summarized - a conodont-based definition of the base of Stage 10 would lie within a succession of globally recognized conodont zones, and would not be dependent on the abrupt occurrence of a typically rare agnostoid within a provincial agnostoid/trilobite succession.

\section{An Eoconodontus notchpeakensis FAD for the Stage 10 base}

Eoconodontus notchpeakensis has a global distribution (e.g., Miller 1978; see Fig. 2, Appendix), and no significant differences exist between conodont workers in identifying this bi-elemental euconodont species. As the species' FAD is typically bracketed by biostratigraphically significant earlier- and later-appearing conodonts, the E. notchpeakensis FAD is consequently a globally significant correlation horizon in stratigraphically unbroken successions.

The Eoconodontus notchpeakensis FAD is characteristically preceded by the first occurrences of several Proconodontus species, overlaps that of the earlier-appearing P. muelleri, and precedes the appearance of Cordylodus proavus Müller, 1959. The local FAD of E. notchpeakensis defines the base of a biostratigraphic unit (Eoconodontus Zone of Miller 1980), and its FAD may be accompanied by the FAD of Cambroistodus cambricus (Miller, 1969) (e.g., Miller et al. 1982, 2006; Chen 1986) a species which typically has its local FAD in the lower Eoconodontus Zone. Other conodonts [i.e., Proconodontus serratus Miller, 1969, and Cambroistodus minutus (Miller, 1969)], appear higher in the Eoconodontus Zone, and are useful in subdivision of the Eoconodontus Zone (e.g., An 1982; Miller et al. 1982, 2006).

Habitat preferences and faunal provincialism naturally accompanied these early euconodont faunas, but these features actually help aid in inter-habitat and -continental correlation of the Eoconodontus notchpeakensis FAD and Zone. For example, Eoconodontus alisonae Landing, 1983, appears somewhat above the E. notchpeakensis FAD in slope successions marginal to carbonate platforms (Landing 1983, 1993; Barnes 1988). Indeed, E. alisonae is so characteristic of slope intervals above the E. notchpeakensis FAD that the upper part of Miller's Eoconodontus Zone has been designated the E. alisonae Zone in Kazakhstan (Apollonov et al. 1988, Dubinina 2000).

The diachroneity of the Cordylodus andresi FAD has been discussed above, with the species appearing in the lowest $C$. proavus Zone on the Laurentian platform, but it appears lower within the Eoconodontus Zone in continental slope successions marginal to tropical platforms (see C. proavus in Landing 1983 as re-identified as C. andresi in Landing et al. 2007b and synonym of $C$. primitivus in
Apollonov et al. 1988, Barnes 1988, and Dubinina 2000). Most significantly, $C$. andresi has an FAD in somewhat older strata in cool-water successions of Baltica and Mexican West Gondwana.

Szaniawski \& Bengtson (1998) recorded Cordylodus andresi with Proconodontus serratus and P. muelleri in Sweden, and concluded that the $C$. andresi Zone in Baltica was the apparent correlative of the Eoconodontus Zone and terminal Proconodontus muelleri Zone as known in Laurentia (e.g., Miller 1980). Additional data supporting their conclusion was supplied by platform and slope successions in southern Mexico, where the $C$. andresi FAD occurs with P. muelleri and just below the E. notchpeakensis FAD. Thus, the $C$. andresi FAD in a reasonably conodont-rich, cool-water succession can provide a datum close to, but slightly below the Eoconodontus notchpeakensis FAD and Zone.

\section{HERB carbon isotope excursion}

The HERB event is a powerful negative carbon isotope excursion in the Stage 10 interval (Ripperdan 2002) "HERB" is a whimsical, culinary-inspired expression that evokes the preceeding positive SPICE event (Fig. 1). The HERB event preceeds the younger, negative TOCE event higher in Stage 10 at about the base of the Cordylodus proavus Zone (Zhu et al. 2007).

The HERB event has received considerable discussion from its presence in the Great Basin, U.S.A., and at Black Mountain, Queensland, Australia (Ripperdan et al. 1992, Ripperdan \& Miller 1995, R.L. Ripperdan in Miller et al. 2006) (Fig. 5). As noted by Ripperdan (in Miller et al. 2006, p. 400), the very shape of the profile of the HERB event allows for precise transcontinental correlations between East Gondwana and western Laurentia. Perhaps even more significant for global correlation are two factors -1) the onset of the HERB event and the beginning of the fall of $\delta^{13} \mathrm{C}$ values toward negative values takes place at about the Eoconodontus notchpeakensis FAD and 2) the maximum negative values of the HERB event are in the lower Eoconodontus Zone.

Thus, the HERB event provides brackets on the lowest and lower parts of the range of Eoconodontus notchpeakensis. In addition, the HERB event allows non-conventional (chemostratigraphic), intercontinental correlation of a GSSP primarily defined by an E. notchpeakensis FAD even if a local section lacks fossils.

Indeed, an example where the HERB event is strongly expressed and provided a basis for correlation is known in locally unfossiliferous, east Laurentian continental slope facies at Green Point, western Newfoundland. R. Ripperdam (personal communication, 2010) has recorded the HERB event within a small outcrop of carbonate rock (Bed 
Figure 4. Conodont and traditional Laurentian platform trilobite biostratigraphy of the upper Jiangshanian-lowest Ordovician. Modified from Landing et al. (2010c, fig. 1).

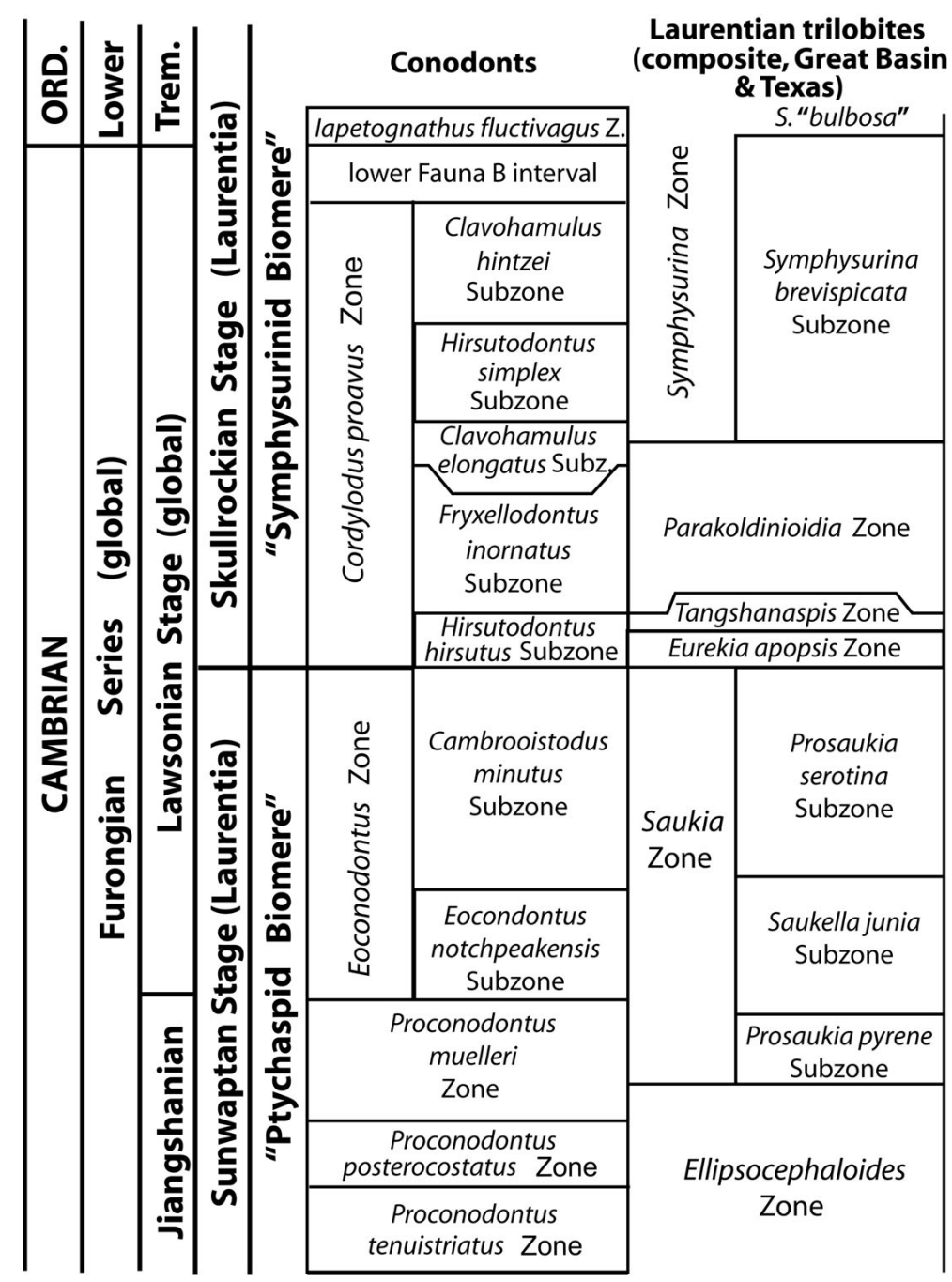

4) near the base of the Green Point section (e.g., Barnes 1988). The presence of the HERB event in bed 4 of the section means that the 'theoretical' FAD of E. notchpeakensis at Green Point - if any conodonts were to be recovered would be in Bed 2 or 3 .

\section{Global correlation of the Eoconodontus notchpeakensis Zone}

A biostratigraphically correlatable horizon defined by the Eoconodontus notchpeakensis FAD (i.e., the base of the Eoconodontus Zone) or, as a proxy, a Cordylodus andresi FAD in cool-water successions, is recognizeable from shallow to marginal, deeper-water successions at localities on most Cambrian continents where conodont studies have been undertaken (Fig. 2, Appendix). In addition, available evidence indicates that this horizon can be identified by the onset of the HERB carbon isotope excursion event (Fig. 5).

The FAD of Eoconodontus notchpeakensis is also reg- ularly accompanied by shallow- to deeper-water polymeroid and agnostoid assemblages. Extensive work on carbonate platforms shows the E. notchpeakensis FAD is in the lower Saukiella junia Subzone of the traditional Saukia Zone in the western, south-central, and north-central Laurentia (e.g., Miller 1980) (Fig. 4) and within the Alborsella Zone in northern Iran (B. Kushan in Müller 1973), the upper Quadratocephalus Zone in South-northeast China and Korea (An 1982, Lee 2004, Choi et al. 2004), and upper Sinosaukia impages Zone of the Chatsworth Limestone, north Queensland, Australia (Nicoll \& Shergold 1991).

In slope and marginal successions, the Eoconodontus notchpeakensis FAD lies at approximately comparable levels based on the resolution allowed by marginal trilobite-based correlations (i.e., Shergold \& Geyer 2003) and the associated conodont succession. Thus, the E. notchpeakensis FAD occurs with trilobites of the upper Yukonaspis Zone and Keithia schucherti Fauna in western and eastern Laurentia (e.g., Landing et al. 1980, Landing 1983, Taylor et al. 1991) - trilobites which suggest a less 


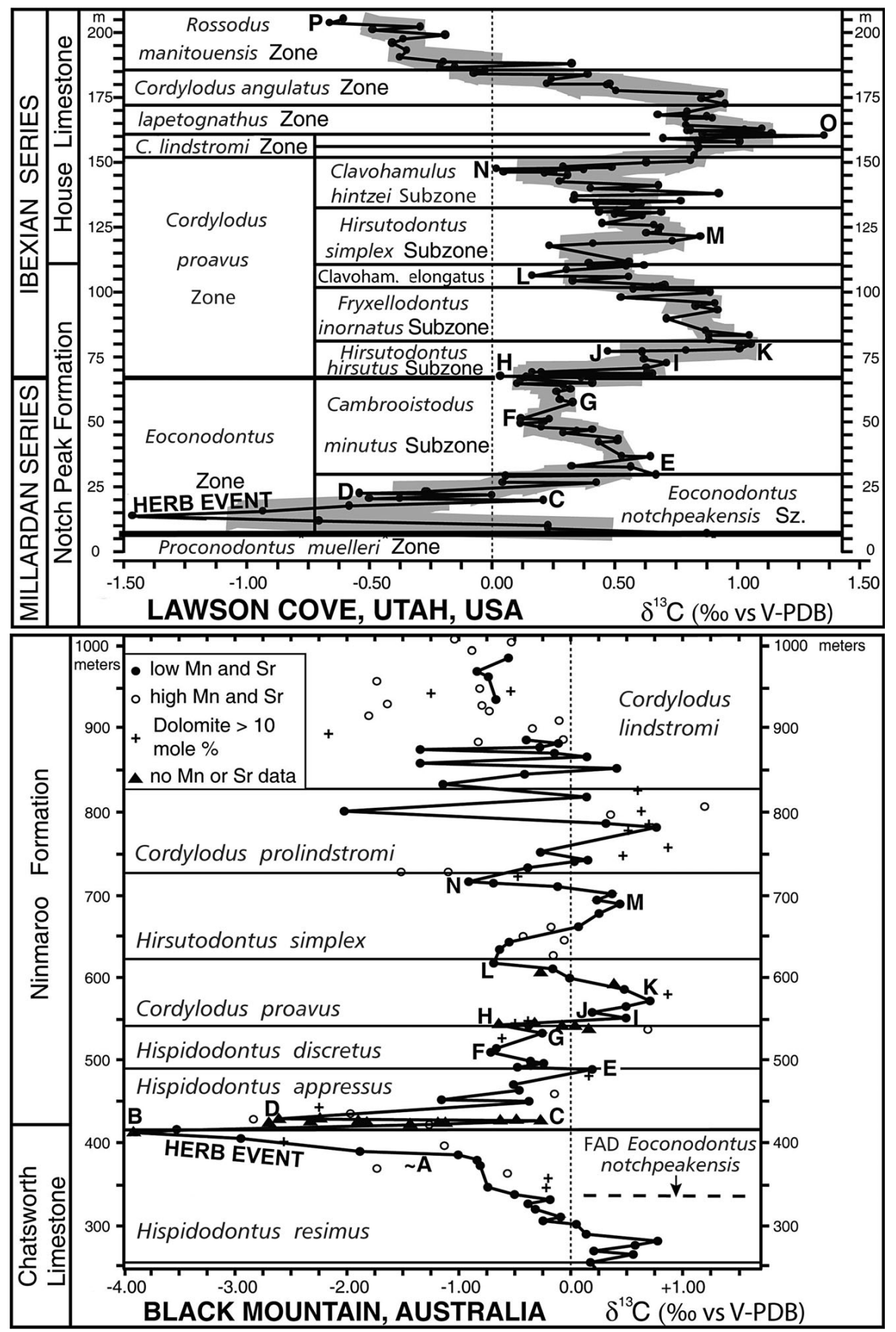

Figure 5. Relation of HERB carbon isotope excusion to Eoconodontus notchpeakensis $\mathrm{FAD}$ and $E$. notchpeakensis Zone in Laurentia and East Gondwana. Modified from Miller $e t$ al. (2006, fig. 12). E. notchpeakensis FAD at Black Mountain from Nicoll \& Shergold (1991).

highly resolved correlation with the Laurentian middle Saukia Zone (e.g., Westrop 1995), in strata correlated with the upper Quadratocephalus Zone in northeast China (Chen 1986), and in the Lophosaukia Zone in Kazakhstan (Apollonova et al. 1988, Dubinina 2000).

The lowest specimens of Eoconodontus notchpeakensis occur in platform and upper slope facies of the lower Tiñu Formation in Mexican West Gondwana above the Cordylodus andresi FAD (Landing et al. 2007a). Although definition of a biostratigraphically significant $E$. notchpea- kensis FAD can be readily done in the lower Tiñu Formation, the FAD is from a part of the section with provincial (Gondwanan) species of geographically widespread trilobite genera. Thus, forms such as Neoparabolina frequens (Barrande, 1868) [= Parabolina argentina (Kayser, 1876)], Mictosaukia globosa (Robison \& Pantoja-Alor, 1968), and "Richardsonella" variagranulata (Robison \& Pantoja-Alor, 1968)] only indicate a generalized correlation into the Upper Cambrian of Avalon and Baltica (Shergold 1988). 
The Avalon and Baltic paleocontinents provide relatively poorly resolved Eoconodontus notchpeakensis FADs. Landing et al. (1978) showed that Cordylodus proavus appears in the Westergaardia Subzone of the middle Acerocare Zone of Avalonian New Brunswick, and this puts an upper bracket on the correlation of the Eoconodontus Zone in the Avalonian and Baltic trilobite successions. The underlying upper Peltura Zones yield Proconodontus serratus, a chararacteristic form of the Eoconodontus Zone, along with Cordylodus andresi in the Peltura scarabaeoides Zone of Sweden (Szaniawski \& Bengtson 1998). As noted by Szaniawski \& Bengtson, the Cordylodus primitivus specimens illustrated by Müller \& Hinz (1991) associated with $P$. serratus from the P. scarabaeoides Zone of Sweden are also referable to $C$. andresi.

The lower limit of the range of Eoconodontus notchpeakensis in Avalon and Baltica may be in the middle Peltura Zones (Peltura minor Zone). Although specimens of Proconodontus muelleri have basal cavities that extend to the tip of the element (Miller 1968, 1980), Müller \& Hinz (1991, fig. 22B, C) illustrated elements in which the basal cavity does not extend to the tip of the element and thus are comparable to E. notchpeakensis. However, the provenance and repository numbers of these specimens are not recorded, and it cannot be determined if they are from the middle or upper Peltura Zones (see Westrop et al., this volume, for illustration of Avalonian trilobite zonation).

\section{Proposal of the Lawsonian Stage}

\section{Lawsonian Stage definition}

The proposed Lawsonian Stage (Fig. 1) is to be the third and highest stage of the Furongian Series and the terminal stage of the Cambrian System. The base of the stage is defined at a GSSP defined by the Eoconodontus notchpeakensis FAD and the onset of the HERB carbon isotope excursion. Thus, the Lawsonian Stage base defines the top of the Jiangshanian Stage. The top of the Lawsonian Stage is defined by the base of the Ordovician System at the base of the Iapetognathus fluctivagus Zone (Fig. 4). As discussed below, the Lawsonian Stage is named for its reference section at Lawson Cove in the northern Wah Wah Mountains, west-central Utah, while its GSSP is defined at the Steamboat Pass section just to the north in the House Range (Fig. 6).

\section{Biostratigraphic range and carbon isotope events of the Lawsonian Stage}

The Lawsonian Stage consists of three globally recognizeable conodont zones and their correlative biotic (e.g., trilobite, acritarch, etc.) zones. The onset of the HERB negative carbon isotope excursion lies at the base of the stage and its maximum lies low in the Lawsonian Stage. The BOCE negative excursion is in the middle of the Lawsonian at about the level of the Laurentian Eurekia apopsis Zone (Figs 1, 4).

The conodont zones of the Lawsonian Stage include the Eoconodontus Zone, commonly with two recognizeable subzones, a lower E. notchpeakensis Subzone and an upper Cambroistodus minutus Subzone (platform successions) or an upper Eoconodontus alisonae Subzone (marginal successions as those in the Maly Karatau) (e.g., Miller 1980, Dubinina 2000). The second conodont zone is Miller's (1978, 1980) original Cordylodus proavus Zone, with five subzones (in some publications the upper two subzones are termed the $C$. intermedius Zone). The uppermost Lawsonian is the lower part of the traditional conodont Fauna B interval of Ethington \& Clark (1972), or the Cordylodus lindstromi Zone in some publications (e.g., Miller et al. 2003) (Fig. 4).

On the Laurentian platform, the Lawsonian Stage comprises a significant stratigraphic interval that ranges through four trilobite zones [middle-upper Saukia Zone, Eurekia apopsis Zone, Tangshanaspis Zone (traditional Missisquoia depressa Subzone); Parakoldinoidea Zone (traditional Missisquoia typicalis Subzone), and most of the Symphysurina Zone (Landing \& Westrop 2010)].

\section{Estimated duration of Lawsonian Age}

Based on the $\mathrm{ca} 488 \mathrm{Ma}$ date on the base of the Cambrian (Landing et al. 2000) and a ca 491 Ma date on the lower Peltura scarabaroides Zone (Davidek et al. 1998), the Lawsonian has a duration of at least 3 m.y. Thus, it comprises an interval that is longer than the Pleistocene.

\section{Lawsonian Stage GSSP and reference section}

\section{Proposed Lawsonian Stage GSSP}

Possible GSSP localities. - As the Eoconodontus notchpeakensis FAD is well defined from deep- to shallow-water settings on most modern continents (Fig. 2), a GSSP for the Lawsonian Stage (Stage 10) base could be defined on the basis of long-established, readily available, published evidence in a number of countries. For example, the E. notchpeakensis FAD is known in relatively accessible, fossiliferous, trilobite-bearing successions in North and northeast China (An 1982, Chen 1986), Australia (Nicoll \& Shergold 1991), the Maly Karatau in Kazakhstan (Dubinina 2000), and the western Cordillera of Canada and the western and south-central United States (e.g., Landing et al. 1980; Taylor \& Miller 1981; Westrop et al. 1981; Miller et al. 1982, 2003, 2006). Of these potential global reference sections 
for Stage 10, we propose two well described, fossiliferous, localities on the west Laurentian platform in the Great Basin of western Utah for the Stage 10/Lawsonian Stage GSSP and reference sections. These sections are proposed as they show the E. notchpeakensis FAD within fossiliferous sections (trilobites, brachiopods) and show the position of the HERB carbon excursion.

Geographic setting of Lawsonian Stage sections in western Utah. - The Eoconodontus notchpeakensis FAD and HERB event been determined at a number of localities in the House and Wah Wah ranges, as well as in other ranges in western Utah (Miller 1969; Miller et al. 2003, 2006) (Fig. 6). These ranges have relatively gently dipping, parautochthonous successions in the middle Mesozoic Sevier thrust belt. The relatively modest relief of the Great Basin reflects extension and listric faulting that began in the earliest Tertiary (e.g., Snoke et al. 1997).

Access. - The Lawsonian Stage GSSP and reference section are in an unpopulated, semidesert terrane, with the beds often exposed for tens of kilometers along strike. The region can be reached at low cost by airline flights into Salt Lake City. U.S. Highway 50 allows access to the House Range and Wah Wah Ranges (Fig. 6), and a two wheel-drive vehicle can follow the gravel roads and dirt tracks along the base of the mountains to the Steamboat Pass GSSP section (Fig. 6). A two wheel-drive auto can drive across most of the low-lying, but completely exposed Lawson Cove reference section.

Preservation. - The Lawsonian Stage GSSP at the Steamboat Pass section in the House Range and its reference section at Lawson Cove in the northern Wah Wah Range lie on public, U.S. government land supervised by the Bureau of Land Management. These sections, like that of the Drumian Stage GSSP (see Babcock et al. 2004), will be preserved, remain accessible for research, and not be lost to development.

Geologic setting. - The House and Wah Wah Ranges in western Utah have a thick Cambrian succession ( ca $3 \mathrm{~km}$ ) overlain by $c a 1.5 \mathrm{~km}$ of Ordovician strata (e.g., Miller $e t$ al. 2006). Volcanic ashes, which could provide geochronometric dates on the Cambrian, are unfortunately unknown in the upper Mesoproterozoic-Lower Paleozoic of the Great Basin as western Laurentia long comprised a passive margin (e.g., Christie-Blick 1997).

In west-central Utah, the Furongian Series is a carbonate platform succession of the upper Orr Formation - the lower House Limestone, and is about $575 \mathrm{~m}$ thick (Fig. 7). The Paibian Stage, $c a 100 \mathrm{~m}$, is the thinnest Furongian stage, but is thicker than the Drumian Stage $(87 \mathrm{~m})$ at its global stratotype section in the Drum Mountains just to the

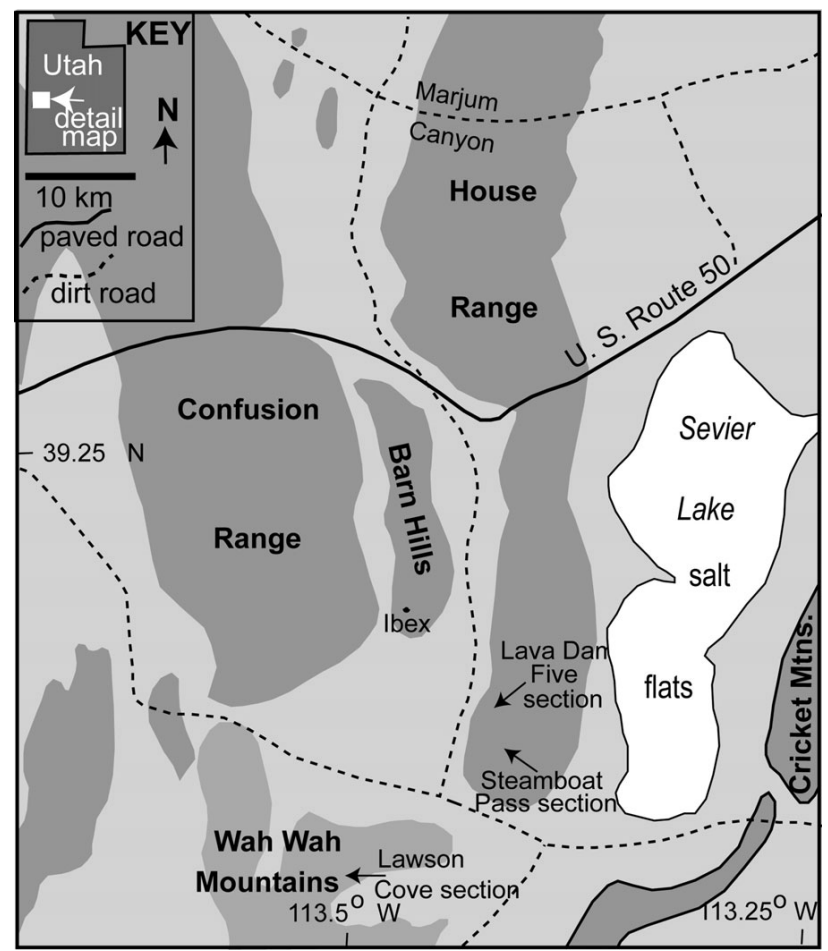

Figure 6. Location of Steamboat Pass GSSP and Lawson Cove reference sections in western Utah. Modified from Miller et al. (2006, fig. 2).

northeast of the House Range (see Babcock et al. 2007). The base of the Lawsonian Stage and Eoconodontus notchpeakensis FAD is in the fossil-hash-rich Red Tops Member of the middle Notch Peak Formation. After much paleontological and sedimentological work, no temporally significant unconformities have been observed in the Lawsonian Stage of the House and Wah Wah ranges (measurements on base of Eoconodontus Zone from Taylor \& Miller 1981; Hintze et al. 1988; Miller et al. 2003, 2006).

This definition of the Lawsonian base at the Eoconodontus notchpeakensis FAD means that the Jiangshanian Stage, or middle Furongian, is about $340 \mathrm{~m}$ thick in the House and Wah Wah Ranges (Fig. 7). The Lawsonian has a thickness of $\mathrm{ca} 150 \mathrm{~m}$, with $153 \mathrm{~m}$ reported at Lawson Cove (i.e., Eoconodontus notchpeakensus FAD-base Ordovician) (Miller et al. 2006).

\section{Definition of base of Lawsonian Stage GSSP}

Steamboat Pass GSSP. - The Lawsonian Stage GSSP at Steamboat Pass and its reference section at Lawson Cove are discussed in much greater detail by Miller et al. (this volume). At the Steamboat Pass section, the Lawsonian Stage base is the Eoconodontus notchpeakensis FAD $21.3 \mathrm{~m}$ above the base of the Red Tops Member (40 m-thick) of the Notch Peak Formation. This horizon is 
in the SW $1 / 4, \mathrm{NW} 1 / 4$ of section 18, T. $23 \mathrm{~S}, \mathrm{R} .13 \mathrm{~W}$ of The Barn quadrangle (Fig. 6). The section must be climbed up to on the ridge north of Steamboat Pass in the southwest House Range, Millard County, Utah (Taylor \& Miller 1981, figs 33, 34; Miller et al. 1982, figs 3, 8).

Previous work. - The GSSP at the Steamboat Pass section (e.g., Miller 1969, pp. 414-416) has ca $330 \mathrm{~m}$ of lower Notch Peak Formation and upper Orr Formation under the Eoconodontus notchpeakensis FAD and Lawsonian Stage base. These strata exhibit the Jiangshanian Stage and include about $20 \mathrm{~m}$ of Proconodontus muelleri Zone under the Lawsonian. Trilobites of the traditional Laurentian Saukiella junia Subzone of the Saukia Zone (Fig. 5) above and below the E. notchpeakensis FAD allow correlation across the Laurentian platform (Miller et al. 1982). The Steamboat Pass section extends as high as the Fryxellodontus inornatus Subzone of the Cordylodus proavus Zone. Higher strata through the Clavohamulus hintzei Subzone of the lower House Limestone are present in the composite Steamboat Pass-Lava Dam Five section (Miller 1969; Miller et al. 1982, fig. 8; Hintze et al. 1988) (Figs 6, 7). As noted by Miller et al. (2006) almost every sample from the uppermost Cambrian in this part of the Great Basin yields a few dozen to several hundred conodont elements.

\section{Lawsonian Stage reference section at Lawson Cove}

Previous work. - Lawson Cove in the northern Wah Wah Mountains, Millard County, Utah, is south of the Lawsonian Stage GSSP at the Steamboat Pass section in the southern House Range. It is in the east half of section 4, T. $25 \mathrm{~S}$, R. $15 \mathrm{~W}$ of the Wah Wah Summit quadrangle (Miller et al. 2006, fig. 6). The location, stratigraphy, and faunal succession of the Lawson Cove sequence are thoroughly documented (see Hintze 1974a, b; Hintze et al. 1988, fig. 10; and Miller et al. 2003, 2006 for detailed maps). As discussed above, Miller et al. (2006) proposed a GSSP for the base of Stage 10 in the middle of the Lawson Cove succession. Their GSSP, at the base of the Eurekia apopsis (trilobites) and Cordylodus proavus (conodonts) Zones, was in the middle of the upper member (Lava Dam Member) of the Notch Peak Formation. Miller et al. (2003, 2006) exhaustively described the stratigraphy and fossils (conodonts and trilobites) of the Lawsonian Stage (i.e., from the Eoconodontus notchpeakensis FAD and onset of HERB event through basal Ordovician Iapetognathus fluctivagus Zone) at Lawson Cove.

Lawson Cove is selected as a reference section as it records the FAD of Eoconodontus notchpeakensis (Miller et al. 2006, fig. 6) and onset of the HERB event (Miller et al. 2006, fig. 12a) (Fig. 5). The HERB event is likely associ-

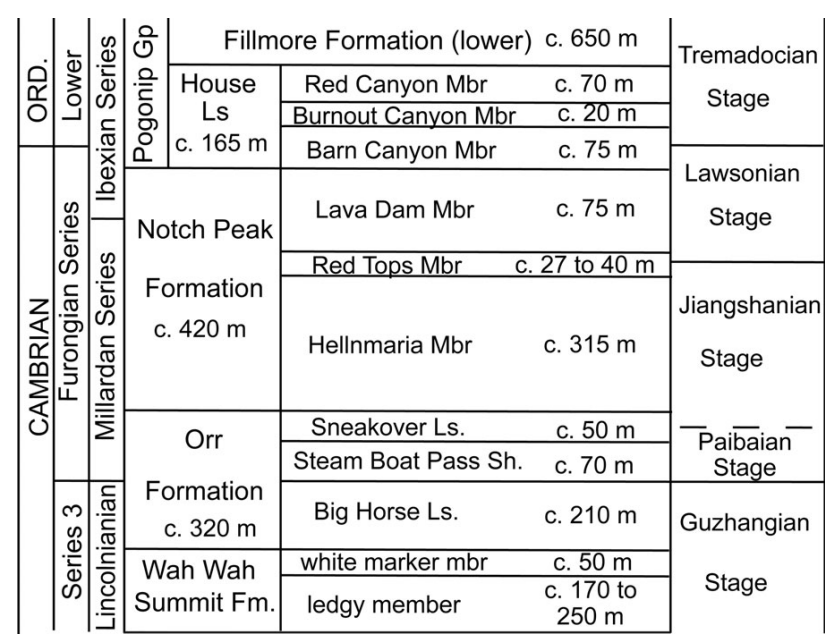

Figure 7. Furongian Series in the southern House Range, west-central Utah.

ated with the Steamboat Pass GSSP as that section is relatively distant from the Oligocene Notch Peak intrusion, but data on carbon isotope stratigraphy were not available for the writing of this report. The biotic and chemostratigraphic features that define the Lawsonian Stage base are $7.0 \mathrm{~m}$ above the base of the Lawson Cove section. As only the upper Proconodontus muelleri Zone is exposed and older faunal and chemostratigraphic developments are covered, the Lawson Cove section is regarded as a reference section of the Lawsonian Stage.

The 153 m-thick Lawson Cove section exposes all of the Lawsonian Stage to its top at the base of the Ordovician, and extends into the middle Lower Ordovician (Rossodus manitouensis Zone, conodonts) (Miller et al. 2006). The accessibility of Lawson Cove led us to base the name of the terminal Cambrian stage on this section (Landing et al. 2010a).

\section{Discussion}

The proposal of the Lawsonian Stage as the third stage of the Furongian Series and terminal stage of the Cambrian System is based on a particularly useful GSSP that is best described as "multifaceted". We do not base the GSSP of Stage 10 on the FAD of a rare, taxonomically problematical species (e.g., Terfelt \& Ahlberg 2010), but rather on a taxonomically "non-controversial" conodont which is readily identified. In addition, we did not select a species that is characteristically so highly habitat-limited (i.e., limited to primarily dysoxic facies as most agnostoids) that it precludes precise correlations onto the extensive, oxygenated platforms of the terminal Cambrian.

What we regard as the "Lotagnostus americanus problem" precludes any attempt to use this species, named from disarticulated sclerites from east Laurentia, as the basis for a basal Stage 10 basal GSSP. The problem originated with 
a taxonomic error - Ludvigsen \& Westrop (in Ludvigsen et al. 1989) erred in defining a broad concept for L. americanus that cannot be justified following restudy of the relavent types (Westrop et al., this volume). Peng \& Babcock (2005) compounded this error, in part by misinterpreting Ludvigsen \& Westrop's discussion, by subsuming a variety of strongly furrowed to almost completely effaced sclerites and specimens in L. americanus. From study of additional material, we have rectified these errors and conclude that $L$. americanus cannot be recognized outside of its type area in Quebec.

Our definition of the GSSP for the base of the Lawsonian Stage includes but is not limited to the FAD of a readily preserved fossil (i.e., phosphatic conodont elements) whose frequently abundant remains are easily recoverable by simple bulk processing of carbonate-rich rock (by such weak acids as acetic and formic acid) or mudstone (by kerosine and hot water washes or Quaternary-O breakdown). Eoconodontus notchpeakensis elements occur from peritidal to deeper-marine facies, and are much more widespread in terms of habitat and geographic distribution than any agnostoid (Fig. 2).

Besides use of the FAD of an organism, the Lawsonian Stage proposal features the use of an associated, intense, negative carbon isotope excursion, the HERB event, for the first time in the definition of this Cambrian chronostratigraphic unit (Fig. 5). The significance of the HERB event in definition of the Lawsonian is that it would allow very precise intercontinental correlations, even into nonfossiliferous successions. As the residence time of carbon is $100 \mathrm{k} . \mathrm{y}$. or less in the world ocean, the HERB event allows a precision in correlation that is much higher than that characteristically provided by biostratigraphy (e.g., Berner 1999).

The significance of using the Eoconodontus notchpeakensis FAD to define and correlate the base of the Lawsonian Stage is that this conodont lies in a succession of conodont faunal assemblages that provide globally extensive, lower and upper brackets on the FAD-species. Thus, zones characterized by early euconodonts (Proconodontus spp.) precede E. notchpeakensis, while the Cambroistodus cambricus FAD is associated or follows the E. notchpeakensis FAD in shallow water. Similarly, Eoconodontus alisonae appears with or follows the E. notchpeakensis FAD in marginal habitats. Species of the Cordylodus proavus Zone provide an upper bracket on the E. notchpeakensis FAD. A further strength of our definition of the Lawsonian Stage is that available evidence from two continents (Baltica and the Mexican margin of West Gondwana) show that the Cordylodus andresi FAD can serve as a proxy for the lower boundary of the E. notchpeakensis $\mathrm{FAD}$ in cool-water successions.

Eoconodontus notchpeakensis has a long range through the Lawsonian Stage and into the lower Tremadocian. However, a long stratigraphic range does not detract from a species' use as a basis to define the base of a Stage 10 interval - the key feature is a consistant FAD and not the last appearance datum (LAD). Wide agreement exists on the species concept of E. notchpeakensis, whereas study of North American material of Lotagnostus raises questions about many previous species identifications (Westrop et al., this volume). With the primary exception of nonfossiliferous facies which do not even yield agnostoids, the lower range of this conodont provides a reliable correlation datum, while the HERB event would allow correlation of the Lawsonian Stage base between fossiliferous and nonfossiliferous successions.

The proposal of the Lawsonian Stage as the replacement of informal Stage 10 as the terminal Cambrian unit means that a significant amount of strata is included in the stage in its global stratotype section in the Steamboat Pass section in the House Mountains, west-central Utah. The $\sim 150$ m-thick global stratotype section is almost twice as thick as that of the Drumian Stage in the nearby Drum Mountains. Finally, the Lawsonian Age has an estimated two to three million year duration, and represents an appreciable amount of geological time that is approximately as long as the Pleistocene.

\section{Acknowledgments}

Landing acknowledges support from the New York State Museum and from earlier National Science Foundation grants. Adrain and Westrop gratefully acknowledge support from National Science Foundation grants EAR 9973065 and EAR 0308685. C. Labandiera, M. Florence, and D. Levin at the National Museum of Natural History, Washington DC; J. Dougherty and M. Coyne at the Geological Survey of Canada, Ottawa; and R. Miller at the New Brunswick Museum, Saint John, facilitated loans of type and other material of Lotagnostus. Xi-Ping Dong and R. Nicoll are thanked for constructive reviews.

\section{References}

ADRAIN, J.M. \& WeSTROP, S.R. 2004. A Late Cambrian (Sunwaptan) silicified trilobite fauna from Nevada. Bulletins of American Paleontology 365, 1-56.

Ahlberg, P. 2003. Trilobites and international tie points in the Upper Cambrian of Scandinavia. Geologica Acta 1, 127-134.

ALLEN, P.M. \& JACKSON, A.A. 1985. Geology of the country around Harlech. Memoir of the British Geological Survey, Sheet 135, with part of 149 (England and Wales), 1-111.

AN, T.-X. 1982. Study on the Cambrian conodonts from north and northeast China. Science Reports of the Institute of Geoscience, University of Tsukuba, Section B, Geological Sciences 3(1), 113-159.

AN, T.-X., ZHANG, F., XIANG, W.-D., ZHANG, Y.-Q., XU, W.-H., ZHANG, H.-J., JiANG, D.-B., YANG, C.-S., LIN, L.-D., CUI, Z.-T. \& YANG, X.-C. 1983. The Conodonts of North China 
and Adjacent regions. 223 pp. Science Press, Beijing. [in Chinese with English abstract]

Apollonov, M.K., ChugaeVA, M.N. \& Dubinina, S.V. 1984. Trilobites and conodonts from the Batyrbay section (uppermost Cambrian-Lower Ordovician) in Maly Karatau Range. 48 pp. Nauka Kazakh SSR Publishing House, Alma-Ata. [in Russian]

Apollonov, M.K., Chugaeva, M.N., Dubinina, S.V \& ZHEMCHUZHNIKOV, V.G. 1988. Batyrbay section, south Kazakhstan, U.S.S.R. - Potential stratotype for the Cambrian-Ordovician boundary. Geological Magazine 25(4), 445-449. DOI 10.1017/S0016756800013066

BABCOCK, L.E., PEnG, S., GeYER, G. \& SHERGOld, J.H. 2005. Changing perspectives on Cambrian chronostratigraphy and progress toward subdivision of the Cambrian System. Geosciences Journal 9, 101-106. DOI 10.1007/BF02910572

BABCOCK, L.E., Robison, R.A., ReES, M.N., PenG, S. \& SALTZMAN, M.R. 2007. The Global boundary strratotype section and point (GSSP) of the Drumian Stage (Cambrian) in the Drum Mountains, Utah, USA. Episodes 30, 84-94.

BAGNOLI, G., BARNES, C.R. \& STEVENS, R.K. 1987. Lower Ordovician (Tremadocian) conodonts from Broom Point and Green Point, western Newfoundland. Bollettino della Società Paleontologica Italiana 27, 145-158.

BAO, J.S. \& JAGO, J.B. 2000. Late Late Cambrian trilobites from near Birch Inlet, southwestern Tasmania. Palaeontology 43(5), 881-917. DOI 10.1111/1475-4983.00154

BARNES, C.R. 1988. The proposed Cambrian-Ordovician global boundary stratotype section and point (GSSP) in western Newfoundland, Canada. Geological Magazine 125(4), 381-414. DOI 10.1017/S0016756800013042

BARRANDE, J. 1868. Fauna silurienne des environs de Hof en Bavière, 31-110. Published by the author, Prague \& Paris.

Bengtson, S. 1976. The structure of some Middle Cambrian conodonts and the early evolution of conodont structure and function. Lethaia 9(2), 185-206. DOI 10.1111/j.1502-3931.1976.tb00966.x

BERNER, R.A. 1999. A new look at the long-term carbon cycle. GSA Today 9(11), 1-6.

BILLINGS, E. 1860. On some new species of fossils from the limestone at Point Levis opposite Quebec. Canadian Naturalist 5(4), 301-324.

BILlings, E. 1865. Palaeozoic Fossils, Volume 1, 169-344. Geological Survey of Canada, Montreal.

BRogniart, A. 1822. Les trilobites, 1-65. In BRogniarT, A. \& DESMAREST, A.-G. (eds) Historie naturelle des crustacés fossiles, sous les rapports zoölogiques te géologiques. Paris \& Strausbourg.

BRYANT, I.D. \& SMITH, M.P. 1990. A composite tectoniceustatic origin for shelf sandstones at the Cambrian-Ordovician boundary in North Greenland. Journal of the Geological Survey 147, 795-809. DOI 10.1144/gsjgs.147.5.0795

CHEN, J.-Y. (ed.) 1986. Aspects of Cambrian-Ordovician in Dayangcha, China. 410 pp. China Prospect Publishing House, Beijing.

CHRISTIE-BLICK, N. 1997. Neoproterozoic sedimentation and tectonics in west-central Utah, 1-30. In LINK, P.K. \& KowALIS, B.J. (eds) Proterozoic to Recent stratigraphy, tectonics, and volcanology, Utah, Nevada, southern Idaho and central Mexico. Brigham Young University Geology Studies 41(1), 1-527.
ChoI, D.K., Chough, S.K., Kwon, Y.K., LeE, S.-B., WoO, J., KANG, I., LEE, H.K., LEE, S.M., SOHN, J.W., SHINN, Y.J. \& LEE, D.-J. 2004. Taebaek Group (Cambrian-Ordovician) in the Seokgaejae section, Taebaeksan Basin: a refined Lower Paleozoic stratigraphy in Korea. Geosciences Journal 8(2), 125-151. DOI 10.1007/BF02910190

CLARK, T.H. 1924. The paleontology of the Beekmantown Series at Levis, Quebec. Bulletins of American Paleontology 10, 21-154.

COOPER, R.A., NOWLAN, G.S. \& WILLIAMS, S.H. 2001. Global stratotype section and point for base of the Ordovician System. Episodes 24, 19-28.

DAVIDEK, K., LANDING, E., BOWRING, S.A., WeStrop, S.R., Rushton, A.W.A. \& ADRAIN, J.M. 1998. New uppermost Cambrian U-Pb date from Avalonian Wales and age of the Cambrian-Ordovician boundary. Geological Magazine 135, 305-309. DOI 10.1017/S0016756898008711

DONG, X.-P. 1985. Conodont-based Cambrian-Ordovician boundary at Huang-achang in Yichang, Hubei, 383-412. In NANJING InSTITUTE OF GEOLOGY AND PALAEONTOLOGY, ACADEMIA SINICA (ed.) Stratigraphy and Palaeontology of Systemic Boundaries in China, Cambrian-Ordovician Boundaries 2. Anhui Science and Technology Publishing House, Hefei.

Dong, X.-P. 1987. Late Cambrian and Early Ordovician conodonts from Chuxian, Anhui, 135-184. In NANJING INSTITUTE of GeOlOGY AND PAlaeOnTOlogy, ACADEMIA SiniCA (ed.) Collection of Postgraduate Theses No. 1. Jiangsu Science and Technology Publishing House. [in Chinese with English abstract]

DonG, X.-P. 1990. A potential candidate for the Middle-Upper Cambrian Boundary stratotype - an Introduction to the Paibi section in Huayuan, Hunan. Acta Geologica Sinica 3(3), 309-327.

DONG, X.-P., REPETSKI, J.E. \& BERGSTRÖM, S.M. 2004. Conodont biostratigraphy of the Middle Cambrian through lowermost Ordovician in western Hunan, China. Acta Geologica Sinica 78(6), 1185-1206.

DUBININA, S.V. 2000. Conodonts and zonal stratigraphy of the Cambrian-Ordovician boundary deposits. Trudy Rossiyskaya Akademiya Nauk, Geologicheskiy Institut 517, 1-239.

ERGALIEV, G.K. 1980. Middle and Upper Cambrian trilobites of the Lesser Karatau, Alma-Ata. 211 pp. Kazakhstan SSR Academy of Sciences, Kazakhstan SSR Publishing House, Alma-Ata. [in Russian]

ERGALIEV, G.K. 1983. Some trilobites from the Upper Cambrian and Lower Ordovician of the Greater Karatau and Ulutau, 35-66. In APOLLONOV, M.K., BANDELETOV, S.M. \& IVSHIN, N.K. (eds) The Lower Paleozoic Stratigraphy and Paleontology of Kazakhstan. Akademiya Nauk Kazakhskoi SSR, Alma-Ata. [in Russian]

ETHINGTON, R.L. \& CLARK, D.L. 1971. Lower Ordovician conodonts in North America, 63-82. In SwEET, W.C. \& BERGSTRÖM, S.M. (eds) Symposium on conodont biostratigraphy. Geological Society of America Memoir 127, 1-499.

GEYER, G. \& SHERGOLD, J. 2000. The quest for internationally recognized divisions of Cambrian time. Episodes 23, 188-195.

Heinsalu, H., Kaljo, D., KuRVits, T. \& ViIRA, V. 2003. The stratotype of the Orasoja Member (Tremadocian, northeast Estonia): lithology, mineralogy, and biostratigraphy. Proceed- 
ings of the Estonian Academy of Science, Geology 52(3), $135-154$.

HINTZE, L.F. 1974a (issued in 1975). Preliminary geologic map of The Barn quadrangle, Millard County, Utah. U.S. Geological Survey Miscellaneous Field Studies Map MF-633.

HINTZE, L.F. 1974a (issued in 1975). Preliminary geologic map of the Wah Wah Summit quadrangle, Millard County, Utah. U.S. Geological Survey Miscellaneous Field Studies Map MF-635.

HiNTZE, L.F., TAYLOR, M.E. \& MiLlER, J.F. 1988. Upper Cambrian-Lower Ordovician Notch Peak Formation in western Utah. U.S. Geological Survey Professional Paper 1393, 1-30.

Howell, B.F. 1935. Some New Brunswick Cambrian agnostidians. Bulletin of the Wagner Free Institute of Science 10(2), 13-16.

Howell, B.F. 1939. Late Cambrian faunas from Fortune Bay, Newfoundland. Geological Society of America Bulletin 50(12), 1963.

HUTCHINSON, R.D. 1952. The stratigraphy and trilobite faunas of the Cambrian sedimentary rocks of Cape Breton Island, Nova Scotia. Geological Survey of Canada Memoir 263.

HutChinSON, R.D. 1962. Cambrian stratigraphy and trilobite faunas of southeastern Newfoundland. Geological Survey of Canada Bulletin 88, 1-156.

Kaljo, D., Borovko, N., Heinsalu, H., Khasanovich, K., Mens, K., Popov, L., SERGEeVA, S., SObOlEVSKaya, R. \& VIIRA, V. 1986. The Cambrian-Ordovician boundary in the Baltic Lagoda Clint area (north Estonia and Leningrad region), USSR). Proceedings of the Academy of Sciences of the Estonian SSR, Geology 35, 97-108.

KAYSER, E. 1876. Beitrage zur Geologie und Paläontologie der Argentinischen Republik. Über primordiale und untersilurische Fossilien aus der Argentinischen Republik. Paläontographica, Supplement 3(2), 1-33.

LANDING, E. 1983. Highgate gorge: Upper Cambrian and Lower Ordovician continental slope deposition and biostratigraphy, northwestern Vermont. Journal of Paleontology 57, $1149-1187$.

LANDING, E. Cambrian-Ordovician boundary in the Taconic allochthon, estern New York, and its interregional correlation. Journal of Paleontology 67(1), 1-19.

LANDING, E. 1996. Avalon - Insular continent by the latest Precambrian, 27-64. In NANCE, R.D. \& THOMPSON, M. (eds) Avalonian and related peri-Gondwanan terranes of the circum-North Atlantic. Geological Society of America, Special Paper 304.

LANDING, E. 1998a. Avalon 1997 - A pre-meeting viewpoint, 1-3. In LANDING, E. \& WESTROP, S.R. (eds) AVALON 1997 The Cambrian standard. Third International Field Conference of the Cambrian Chronostratigraphy Working Group and I.G.C.P. Project 366 (Ecological Aspects of the Cambrian Radiation). New York State Museum Bulletin 492.

LANDING, E. 1998b. Cambrian subdivisions and correlations: introduction. Canadian Journal of Earth Sciences 35, 321-322. DOI 10.1139/e98-013

LANDING, E. 2007. East Laurentia 2007 - a pre-meeting statement, 3-4. In LANDING, E. (ed.) Ediacaran-Ordovician of east Laurentia -S.W. Ford memorial volume. New York State Museum Bulletin 510, 1-93.

LANDING, E., BENUS, A.P. \& WHITNEY, P.R. 1992. Early and early Middle Ordovician continental slope deposition: shale cycles and sandstones in the Quebec Reentrant and New York Promontory region. New York State Museum Bulletin 474, 1-40.

LANDING, E., ENGLISH, A. \& KePPIE, J.D. 2010a. Cambrian origin of all skeletalized metazoan phyla - discovery of Earth's oldest bryozoans (Upper Cambrian, southern Mexico). Geology 38, 547-550. DOI 10.1130/G30870.1

LANDING, E., FrANZI, D.A., HAGADORN, J.W., WeStROP, S.R., KRÖGER, B. \& DAWSON, J.C. 2007b. Cambrian of east Laurentia: field workshop in eastern New York and western Vermont, 25-80. In LANDING, E. (ed.) Ediacaran-Ordovician of east Laurentia - S.W. Ford memorial volume. New York State Museum Bulletin 510, 1-93.

LANDING, E., LUDVIGSEN, R. \& VON BITTER, P.H. 1980. Upper Cambrian-Lower Ordovician conodont biostratigraphy and biofacies, District of Mackenzie. Royal Ontario Museum Life Sciences Contributions 126, 1-44.

LANDing, E., TAYLOR, M.E. \& ERDTMAnN, B.-D. 1978. Correlation of the Cambrian-Ordovician boundary between the Acado-Baltic and North American faunal provinces. Geology 6(2), 75-78.

DOI 10.1130/0091-7613(1978)6<75:COTCBB >2.0.CO;2

LANDING, E., WeStRoP, S.R. \& KEPPIE, J.D. 2007a. Terminal Cambrian and lowest Ordovician succession of Mexican West Gondwana - biotas and sequence stratigraphy of the Tiñu Formation. Geological Magazine 144, 909-936.

LANDing, E., WeStrop, S.R., KRÖGER, B. \& ENGLiSh, A.M. 2010. Left behind - delayed extinction and a relict trilobite fauna in the Cambrian-Ordovician boundary succession (northeast Laurentia, New York). Geological Magazine 148, 529-557. DOI 10.1017/50016756810000919

LANDING, E., WeStroP, S.R. \& MiLLER, J.F. 2010b. Globally practical base of the uppermost Cambrian (Stage 10)-FAD of the conodont Eoconodontus notchpeakensis and the Lawsonian Stage, 18. In FATKA, O. \& BUDIL, P. (eds) The $15^{\text {th }}$ Field Conference of the Cambrian Stage Subdivision Working Group, International Subcommission on Cambrian Stratigraphy. Abstracts and Excursion Guide, Prague, Czech Republic and south-eastern Germany. Czech Geological Survey, Prague.

LEE, B.-S. 2001. Conodont biostratigraphy of the Hwajeol Formation (Upper Cambrian) in northern Taegaeg City, Korea. Ameghiniana 38(4), 441-453.

LEE, H.-Y. 1975. Conodonts from the Upper Cambrian formation, Kangweon-Do, South Korea and its stratigraphic significance. Yonsei University Graduate School 12, 71-89.

LINNARSSON, J.G.O. 1880. Om försteningame i de svenska largen med Peltura och Sphaerophthalmus. Sveriges Geologiska Undersökning 43(1), 1-31.

LISAGOR, K.A. 1977. Biostratigraphy and trilobites of the Upper Cambrian and Tremadocian of Maly Karatau (soughern Kazakhstan). Trudy Akademiya Nauk SSSP, Sibirskoe Otdelenie, Institut Geologii i Geofiziki 313, 197-265. [in Russian]

LONGACRE, S.A. 1970. Trilobites of the Upper Cambrian Ptychaspid Biomere, Wilberns Foprmation, central Texas. Paleontological Society Memoir 4, 70 p.

LU, Y. 1964. Cambrian trilobites, 26-39. In WANG, Y. (ed.) A Handbook of Index Fossils of South China. Science Press, Beijing.

LUDVIGSEN, R. 1982. Upper Cambrian and Lower Ordovician trilobite biostratigraphy of the Rabbitkettle Formation, west- 
ern District of Mackenzie. Royal Ontario Museum Life Sciences Contributions 134, 1-188.

Ludvigsen, R., Westrop, S.R. \& Kindle, C.H. 1989. Sunwaptan (Upper Cambrian) trilobites of the Cow Head Group, western Newfoundland, Canada. Palaeontographica Canadiana $6,1-175$.

MATTHEW, G.F. 1894. Illustrations of the fauna of the St. John Group, 8. Transactions of the Royal Society of Canada 11(4), 85-129.

MATTHEW, G.F. 1903. Report on the Cambrian rocks of Cape Breton. 246 pp. Geological Survey of Canada, Ottawa.

MiLlER, J.F. 1969. Conodont faunas and biostratigraphy of the Upper Cambrian and lowest Ordovician, House Range, Utah. Journal of Paleontology 43, 413-439.

MILlER, J.F. 1978. Upper Cambrian and lowest Ordovician conodont faunas of the House Range, Utah, 1-33. In MiLLER, J.F. (ed.) Upper Cambrian to Middle Ordovician conodont faunas of western Utah. Southwest Missouri State University Geoscience Series 5.

MILLER, J.F. 1980. Taxonomic revision of some Upper Cambrian and Lower Ordovician conodonts with comments onh their evolution. University of Kansas Paleontological Contributions 99, 1-39.

Miller, J.F., Evans, K.R., FreEman, R., RiPPERdan, R. \& TAYLOR, J. 2011. Proposed stratotype for the base of the Lawsonian Stage (Cambrian Stage 10) at the First Appearance Datum of Eoconodontus notchpeakensis (Miller) in the House Range, Utah, USA. Bulletin of Geosciences 86(3), 595-620. DOI 10.3140/bull.geosci.1255

MiLlER, J.F., EvANS, K.R., LOCH, J.D., ETHINGTON, R.L., STITT, J.H., HOLMER, L. \& POPOV, L.E. 2003. Stratigraphy of the Sauk III interval (Cambrian-Ordovician) in the Ibex area, western Millard County, Utah and central Texas. Brigham Young University Geology Studies, Special Publication 7, 1-202.

Miller, J.F., ETHINGTON, R.L., Evans, K.R., HOLMER, L.E., LOCH, J.D., POPOV, L.E., REPETSKI, J.E., RIPPERDAN, R.L. \& TAYLOR, J.F. 2006. Proposed stratotype for the base of the highest Cambrian stage at the first appearance datum of Cordylodus andresi, Lawson Cove section, Utah, USA. Palaeoworld 15, 384-405. DOI 10.1016/j.palwor.2006.10.017

MiLleR, J.F. \& MELBY, J.H. 1971. Tremplealeauan conodonts, 4-9. In CLARK, D.L. (ed.) Conodonts and biostratigraphy of the Wisconsin Paleozoic. University of Wisconsin, Geological and Natural History Survey, Information Circular 19, 151 pp.

MiLlER, J.F. \& REPETSKI, J.E. 2009. Base of the Cordylodus proavus Zone (FAD of Cordylodus andresi) as a key horizon for Late Cambrian global chronocorrelation. Permophiles (Newsletter of the Subcommission on Permian Stratigraphy) 53(1), 32-33.

Miller, J.F., TAYlor, M.E., StitT, J.H., EThington, R.L., HINTZE, L.F. \& TAYLOR, J.F. 1982. Potential Cambrian-Ordovician boundary stratotype sections in the western United States, 155-180. In BASSETT, M.G. \& DEAN, W.T. (eds) The Cambrian-Ordovician boundary: sections, fossil distributions, and correlations. National Museum of Wales, Geological Series 3.

MÜLlER, K.J. 1959. Kambrische Conodonten. Zeitschrift für deutsche geologische Gesellschaft 111, 434-485.

MÜLLER, K.J. 1973. Late Cambrian and Early Ordovician conodonts from northern Iran. Report of the Geological Survey of Iran 30, 1-77.
MÜLlER, K.J. \& HINZ, I. 1991. Upper Cambrian conodonts from Sweden. Fossils and Strata 28, 1-153.

NiCOLL, R.S. 1991. The genus Cordylodus and a latest Cambrian-earliest Ordovician biostratigraphy. BMR Journal of Australian Geology \& Geophysics 11, 529-558.

NiCOLL, R.S. \& SHERGOLD, J.H. 1991. Revised Late Cambrian (pre-Paytonian-Datsonian) conodont biostratigraphy at Black Mountain, Goergina Basin, western Queensland, Australia. BMR Journal of Australia Geology \& Geophysics 12(1), 93-118.

NORTH AMERICAN COMMISSION ON STRATIGRAPHIC NOMENCLATURE 1983. North American Stratigraphic Code. American Association of Petroleum Geologists Bulletin 67(8), 841-875.

NOWLAN, G.S. 1985. Late Cambrian and Early Ordovician conodonts from the Franklinian miogeosyncline, Canadian Arctic Islands. Journal of Paleontology 59(1), 96-122.

ÖZGUL, N. \& GEDIK, I. 1973. New data on the stratigraphy and conodont fauna of Çaltepe Limestone and Seydișehir Formation, Lower Palaeozoic of central Taurus Range. Bulletin of the Geological Survey of Turkey 16(1), 39-52. [in Turkish]

PALMER, A.R. 1955. Upper Cambrian Agnostidae of the Eureka District, Nevada. Journal of Paleontology 29, 86-101.

PEGEL, T.V. 2001. Evolution of trilobite biofacies in Cambrian basins on the Siberian platform. Journal of Paleontology 74, $1000-1019$.

PENG, S. 1991. Upper Cambrian in the Cili-Taoyuan area, Hunan, and its trilobite succession. Journal of Stratigraphy 14, 261-276. [in Chinese with English summary]

PENG, S. 1992. Upper Cambrian biostratigraphy and trilobite faunas of the Cili-Taoyuan area, northwestern Hunan. Memoirs of the Association of Australasian Palaeontologists 13, 1-119.

PENG, S. \& BABCOCK, L.E. 2005. Two Cambrian agnostoid trilobites, Agnostotes orientalis (Kobayashi, 1935) and Lotagnostus americanus (Billings, 1860): key species for defining global stages of the Cambrian System. Geosciences Journal 9(2), 107-115. DOI 10.1007/BF02910573

PenG, S.C., BABCOCK, L.E., ZUO, J.X., LIN, H.L., ZHU, X.J., YANG, X.F., QI, Y.P., BAGNOLI, G. \& WANG, L.W. 2009. Potential GSSP for the base of Cambrian Stage 9, coinciding with the first appearance of Agnostotes orientalis, Zhejiang, China. Science in China D: Earth Sciences 52(4), 434-451.

Peng, S.C., ZuO, G.X., BABCOCK, L.E., LIN, H.L., ZHOU, C.M., YANG, X.F. \& LI, Q. 2005. Cambrian sections at Dadoushan near Dubian, Jiangshan, western Zhejiang Province and candidate stratotype section for the base of an unnamed globan stage defined by the FAD of Agnostotes orientalis, 210-217. In Peng, S.C., BABCOCK, L.E. \& ZHOU, M.Y. (eds) Cambrian System of China and Korea. University of Science and Technology of China Press, Hefei.

QUi, H., LU, Y., ZHU, Z., BI, D., LIN, T., ZHOU, Z., ZHANG, Q., QIAN, Y., JU, T., HAN, N. \& WEI, X. 1983. Trilobita, 1-657. In NANJing Institute of GeOlogy AND Mineral RESOURCES (ed.) Paleontological Atlas of East China, Part 1: Early Paleozoic. Geological Publishing House, Beijing. [in Chinese]

RASETTI, F. 1944. Upper Cambrian trilobites from the Lévis conglomerate. Journal of Paleontology 18(3), 229-258.

RASETTI, F. 1959. Trempealeauan trilobites from the Conococheague, Frederick, and Grove limestones of the central Appalachians. Journal of Paleontology 33, 375-398. 
RIPPERDAN, R.L. 2002. The HERB event: end of Cambrian carbon cycle paradigm? Geological Society of America Abstracts with Programs 34(6), 413.

RIPPERDAN, R.L., MARGARITZ, M., NICOLL, R.S. \& SHERGOLD, J.S. 1992. Simultaneous changes in carbon isotopes, sea level, and conodont biozones within Cambrian-Ordovician boundary interval at Black Mountain, Australia. Geology 20, 1039-1042.

DOI 10.1130/0091-7613(1992)020<1039:SCICIS >2.3.CO;2

RIPPERDAN, R.L. \& MILLER, J.F. 1995. Carbon isotope ratios from the Cambrian-Ordovician boundary section at Lawson Cove, Wah Wah Mountains, Utah, 129-132. In COOPER, J.D. (ed.) Ordovician odyssey: short papers for the Seventh International Symposium on the Ordovician System. SEPM, Pacific Section 77.

Robison, R. \& PANTOJA-ALOR, J. 1968. Tremadocian trilobites from the Nochixtlan region, Oaxaca, Mexico. Journal of Paleontology 42, 767-800.

Ross, R.J., JR., Hintze, L.F., ETHINGTON, R.L., MiLleR, J.F., TAYLOR, M.E., REPETSKI, J.E., SPRINKLE, J. \& GREUNSBURG, T.E. 1997. The Ibexian, lowermost series in the North American Ordovician, 1-50. In TAYLOR, M.E. (ed.) Early Paleozoic biochronology of the Great Basin, western United States. U.S. Geological Survey Professional Paper 1579, 1-89.

RusCONI, C. 1951. Trilobitos cambricos del Cerro Pelado (Mendoza). Boletín Paleontologico de Beunos Aires 24(1), 1-4.

RUSHTON, A.W.A. 2009. Revision of the Furongian agnostoid Lotagnostus trisectus (Salter). Memoirs of the Association of Australasian Palaeontologists 37(1), 273-279.

SALTER, J.W. 1864. Figures and descriptions illustrative of British organic remains. Decade 11, Trilobites (chiefly Silurian). Memoirs of the Geological Survey of the United Kingdom, 1-64.

SALTZMAN, M.R., RUNNEGAR, B. \& LOHNMAN, K.C. 1998. Carbon isotope stratigraphy of the Upper Cambrian (Steptoean Stage) sequences of the eastern Great Basin: record of a global oceanographic event. Geological Society of America Bulletin 110(2), 285-297.

DOI 10.1130/0016-7606(1998)110<0285:CISOUC >2.3.CO;2

SCHOVSBO, N.H. 2001. Why barren intervals? A taphonomic case study of the Scandinavian Alum Shale and its faunas. Lethaia 34(2), 271-285. DOI 10.1080/002411601753293024

SEPKOSKI, J.J., JR. 1981. A factor analytic description of the Phanerozoic marine fossil record. Paleobiology 7, 36-53.

SEPKOSKI, J.J., JR. 1995. The Ordovician radiations: diversification and extinction shown by global genus-level taxonomic data, 393-396. In COOPER, J.D., DROSER, M.L. \& FINNEY, S.C. (eds) Ordovician odessey: short papers. $7^{\text {th }}$ International Symposium on the Ordovician System. Society for Sedimentary Geology, Pacific Section, Book 77.

SEPKOSKI, J.J., JR. 1997. Biodiversity: past, present, and future. Journal of Paleontology 71, 533-539.

SHERGOLD, J.H. 1972. Late Upper Cambrian trilobites from the Gola Beds, western Queensland. Australia Bureau of Mineral Resources, Geology and Geophysics Bulletin 112, 1-127.

SHERGOLD, J.H. 1988. Review of trilobite biofacies distributions at the Cambrian-Ordovician boundary. Geological Magazine 125, 363-380. DOI 10.1017/S0016756800013030

SHERGOLD, J.H., BORDONARO, O. \& LIÑÁN, E. 1995. Late Cambrian agnostoid trilobites from Argentina. Palaeontology 38, 241-257.
SHERGOLD, J.H. \& GEYER, G. 2003. The Subcommission of Cambrian Stratigraphy: the status quo. Geologica Acta 1(1), 5-9.

SNOKE, A.W., HowArd, K.A., MCGREW, A.J., BurTON, B.R., Barnes, C.G., Peters, M.T. \& Wright, J.E. 1997. The grand tour of the Ruby-East Humboldt metamorphic core complex, northeastern Nevada: Part 1 - introduction \& road log, 225-269. In LiNK, P.K. \& KowALIS, B.J. (eds) Proterozoic to Recent stratigraphy, tectonics, and volcanology, Utah, Nevada, southern Idaho and central Mexico. Brigham Young University Geology Studies 41(1), 1-527.

SoHN, J.W. \& CHOI, D.K. 2007. Furongian trilobites from the Asioptychaspis and Quadraticephalus zones of the Hwajeol Formation, Taebaeksan Basin, Korea. Geosciences Journal 11, 297-314. DOI 10.1007/BF02857047

SZANIAWSKI, H. \& BENGTSON, S. 1998. Late Cambrian euconodonts from Sweden. Palaeontologica Polonica 58, 7-29.

TAYLOR, J.F., KENNEDY, D.J., MILLER, J.F. \& REPETSKI, J.E. 1991. Uppermost Cambrian slope deposits at Highgate gorge, Vermont: a minor miscorrelation with major consequences for conodont and trilobite chronocorrelation. Journal of Paleontology 65, 855-863.

TAYLOR, J.F., REPETSKI, J.E. \& ROEBUCK, C.A. 1996. Stratigraphic significance of trilobite and conodont faunas from the Cambrian-Ordovician shelfbreak facies in the Frederick valley, Maryland, 141-164. In BREZINSKI, D.K. \& REGER, J.P. (eds) Studies in Maryland geology in commemoration of the centennial of the Maryland Geological Survey. Maryland Geological Survey Special Publication 3.

TAYLOR, M.E. 1976. Indigenous and redeposited trilobites from Late Cambrian basinal environments of central Nevada. Journal of Paleontology 50, 668-700.

TAYLOR, M.E. \& COOK, H.E. 1976. Continental shelf and slope facies of the Upper Cambrian and lowest Ordovician of Nevada. Brigham Young University Geology Studies 23, $181-214$.

TAYLOR, M.E. \& MILLER, J.F. 1981. Upper Cambrian and Lower Ordovician stratigraphy and biostratigraphy, southern House Range, Utah, 102-118. In TAYLOR, M.E. \& PALMER, A.R. (eds) Second International Symposium on the Cambrian. Guidebook for Field Trip 1. Cambrian stratigraphy and paleontology of the Great Basin and vicinity, western United States. U.S. Geological Survey and the Subcommission on Cambrian Stratigraphy, Commission on Stratigraphy, International Union of Geological Sciences, Denver.

Terfelt, F. \& AhlBerg, P. 2010. Pseudagnostus rugosus Ergaliev, 1980: a key agnostoid species for intercontinental correlation of upper Furongian strata. Geological Magazine 147(5), 789-796. DOI 10.1017/S0016756810000282

Terfelt, F., AhlberG, P. \& EriKsson, M.E. 2011. Complete record of Furongian polymerid trilobites and agnostoids of Scandinavia - a biostratigraphical scheme. Lethaia 44(1), 8-14. DOI 10.1111/j.1502-3931.2009.00211.x

Terfelt, F., ERIKSSON, M.E., AHLBERG, P. \& BABCOCK, L.E. 2008. Furongian Series (Cambrian) biostratigraphy of Scandinavia - a revision. Norwegian Journal of Geology 88, 73-87.

TORTERro, M.F. \& BORDONARO, O.L. 1997. Cambrian agnostoid trilobites from Mendoza, Argentina: a systematic revision and biostratigraphic implications. Journal of Paleontology 71(1), 74-86.

Troedsson, G.T. 1937. On the Cambro-Ordovician faunas of 
western Quruq Tagh, eastern Tien-Shan. Palaeontologia Sinica 2(1), 1-74.

WALCOTT, C.D. 1914. Dikelocephalus and other genera of the Dikelocephalinae. Smithsonian Miscellaneous Collections 57(13), 345-412.

WANG, Y. (ed.) 1964. A Handbook of index fossils of South China. 173 pp. Science Press, Beijing. [in Chinese]

WANG, Z.H. 1985. Late Cambrian and Early Ordovician conodonts from north and northeast China with the Cambrian-Ordovician boundary, 195-238. In NANJING INSTITUTE OF GEOlogy AND PAlaEOnTOlogy, ACADEMIA SiniCA (ed.) Stratigraphy and paleontology of systematic boundaries in China, Cambrian-Ordovician boundary 2. Nanjing Institute of Geology and Palaeontology, Academica Sinica.

WESTERGÅRD, A.H. 1922. Sveriges olenidskiffer. Sveriges Geologiska Undersökning 18, 1-205.

WeSTROP, S.R. 1986. Trilobites of the Upper Cambrian Sunwaptan Stage, southern Canadian Rocky Mountains, Alberta. Palaeontographica Canadiana 3, 1-179.

WeSTROP, S.R. 1995. Sunwaptan and Ibexian (Upper Cambrian-Lower Ordovician) trilobites of the Rabbitkettle Formation, northern Mackenzie Mountains, northwest Canada. Palaeontographica Canadiana 12, 1-75.

WeSTROP, S.R., AdRAIN, J.M. \& LANDING, E. 2011. The Cambrian (Sunwaptan, Furongian) agnostoid arthropod Lotagnostus Whitehouse, 1936, in Laurentian and Avalonian
North America: systematics and biostratigraphic significance. Bulletin of Geosciences 86(3), 569-594.

DOI 10.3140/bull.geosci.1256

WeSTROP, S.R., LANDing, E. \& LudVIGSEN, R. 1981. Upper Cambrian and Lower Ordovician biostratigraphy, Jasper National Park, Alberta, 45-53. In AITKEN, J.D. \& TAYLOR, M.E. (eds) The Cambrian System in the southern Canadian Rocky Mountains, Alberta and British Columbia. Guidebook for Field Trip 2. Second International Symposium on the Cambrian System. United States Geological Survey, Golden, Colorado.

WhiteHouse, F.W. 1936. The Cambrian faunas of northeastern Australia. Parts 1 and 2. Memoirs of the Queensland Museum $11,59-112$.

Wright, A.J., COOPER, R.A. \& SIMES, J.G. 1994. Cambrian and Ordovician faunas and stratigraphy, Mt Patriarch, New Zealand. New Zealand Journal of Geology and Geophysics 37, 432-476. DOI 10.1080/00288306.1994.9514632

ZHANG, T. 1981. Trilobita, 134-213. In Palaeontological Atlas of northwest China, Xinjiang Uighur Autonomous Regions, Volume 1. Early Palaeozoic. Geological Publishing House, Beijing. [in Chinese]

ZHU, M.-Y., BABCOCK, L.E. \& PENG, S.-C. 2006. Advances in Cambrian stratigraphy and paleontology: integrating correlation techniques, paleobiology, taphonomy and paleoenvironmental reconstruction. Palaeoworld 15, 217-222. DOI 10.1016/j.palwor.2006.10.016

\section{Appendix - References for localities in Fig. 2}

\section{A - Localities with Lotagnostus americanus and related species}

Avalon. - Lotagnostus trisectus (Salter, 1864) in Avalonian localities of England and Wales (Salter 1864; Allen \& Jackson 1985; Davidek et al. 1998, fig. 2; Rushton 2009). In Avalonian Canada, only occurrences in Cape Breton Island, Nova Scotia (Matthew 1901, 1903; Hutchinson 1952) have been verified by study of type and new material (L. cf. L. trisectus and L. germanus in Westrop et al., this volume). Occurrences in south-central Newfoundland from Howell (1939) and Hutchinson (1962, p. 35), but neither report illustrates the "species". The southern New Brunswick occurrences reported by Matthew (1894), who named several subspecies of $A$. trisectus, need to be re-evaluated and are not included in the figure.

Baltica. - Traditionally reported as L. trisectus in Sweden (Linnarsson 1880, Ahlberg 2003, Terfelt \& Ahlberg 2010), but these forms are not demonstrably conspecific with neotype and topotype material of this species as documented by Rushton (2009). The Baltica forms are referred to here as L. "trisectus".

Gondwana (east). - The Kazakhstan and most Chinese successions are marginal to carbonate platforms: the Bolishoi Karatau, Kazakhstan, with specimens first reported as L. asiaticus and L. punctatus by Ergaliev (1983), and those from the Malyi Karatau as L. asiaticus by Lisagor (1977) and Dubinina (2000). The quality of this material and its documentation are poor, and these identifications are questionable. A number of Lotagnostus species were named from Chinese successions from west to east across China: L. punctatus Lu (in Wang, 1964), L. asiaticus Troedsson, 1937 and possibly L. hedini (Troedsson, 1937) from the eastern Tien Shan (now Zhejiang Province) (Lu \& Lin 1989); L. xinjiangensis Zhang, 1981, from northwest Zhejiang; L. ningguoensis by Qian (in Qui et al. 1983) from Anhui; L. punctatus has been recorded from Hunan (Peng 1992). At a minimum, L. asiaticus, L. punctatus and L. hedini are valid species.

Laurentia. - L. americanus is confined to Levis, Quebec, boulders (Billings 1869, 1865; Rasetti 1944; Rushton 2009), with material from western Newfoundland misassigned (Ludvigsen et al. 1989), northern Mackenzie Mountains, Northwest Territories, Canada: L. americanus reported by Westrop (1995) now re-evaluated as an indeterminate species (Westrop et al., this volume). L. obscurus Palmer, 1955, from Eureka District, Nevada, and L. cf. L. obscurus farther east, in the Cherry 
Creek Range (Westrop et al., this volume). Cranidium of Goniagnostus verrucosus (Rusconi, 1951) (synonymized with L. trisectus by Torello \& Bordonaro 1997 but not demonstrably conspecific with neotype and topotype from Malvern, England; see Westrop et al., this volume) from mélange blocks in Laurentian Argentina, Mendoza Province.

Siberian Platform. - Reported as L. trisectus from Khos-Nelege River tributary of Aldan River, northwest Siberia (e.g., Pegel 2000), but not demonstrably conspecific with neotype and topotype material of this species documented by Rushton (2009). The Siberian material is referred to herein as L. "trisectus".

\section{B - Localities with E. notchpeakensis FAD or cool-water successions with Cordylodus andresi FAD as proxy for base of Lawsonian Stage}

Baltica. - C. andresi proxy in Sweden (Szaniawski \& Bengtson 1998) and Estonia (Heinsalu et al. 2003). E. notchpeakensis occurs in the lower or upper Peltura Zones in Sweden; Müller \& Hinz's (1991, fig. 22B, C) E. notchpeakensis specimens were reported as Proconodontus muelleri, although basal cavity of their specimens does not reach tip of element (as in the latter species). However, Müller \& Hinz (1991) did not indicate the horizon or Swedish locality that their E. notchpeakensis specimens came from.

East Gondwana (platform and deeper-water successions). - Possible FAD in incompletely sampled section, Hadin area, southern Turkey (Özgul \& Gedik 1973). FAD established in northern Iran (Müller 1973). Black Mountain, western Queensland (e.g., Nicoll \& Shergold 1991). Numerous successions marginal to and on the Sino-Korean Platform show E. notchpeakensis \pm Cambroistodus cambricus FAD - FAD in north and northeast China include carbonate platform sections at Magezhuang, Hebei, and Huolianzhai, Liaoning (An 1982), with Dayangcha, Jilin Province (earlier a candidate for the Cambrian-Ordovician boundary), a deeper-water succession (e.g., Chen 1986). In South China, Dong (2000; also Dong et al. 2004) record four platform localities with an E. notchpeakensis FAD in west Hunan. The easternmost Sino-Korean Platform has platform successions with an E. notchpeakensis FAD in northeast and east-central South Korea (respectively, Lee 2004, and Choi et al. 2004).

West Gondwana (southern platform and northern slope successions). - C. andresi FAD proxy, Oaxaca State, Mexico (Landing et al. 2007).

Laurentia (platform successions). - Southern Laurentia: Arbuckle and Wichita Mountains, western and southern Oklahoma; composite Threadgill Creek-Lange Ranch section, Llano area, central Texas; and House and Wah Wah Ranges, Utah (Miller 1969, 1978, 1980; Miller et al. 1982, 2003, 2006). Central Laurentia: E. notchpeakensis FAD likely about at lowest recovered E. notchpeakensis elements in upper Mississippi River valley region of Minnesota and Wisconsin (Miller \& Melby 1971). Northern Laurentian areas: Marginal platform regions of west and east Laurentia in Alberta, Canada (Westrop et al. 1981), Baffin Island, Canadian Arctic Archipelago (Nowlan 1985); and North Greenland (Bryant \& Smith 1990).

Laurentia (deep ramp, slope, and rise successions). - Northwest Territory, Canada (Landing et al. 1980); Taconic allochthon, eastern New York (Landing 1993); northwest Vermont (Landing 1983); Frederick valley, Maryland (Taylor et al. 1996); western Newfoundland (Barnes 1988). 